\title{
Hepatitis B Virus X and Regulation of Viral Gene Expression
}

\author{
Betty L. Slagle ${ }^{1}$ and Michael J. Bouchard ${ }^{2}$ \\ ${ }^{1}$ Department of Molecular Virology and Microbiology, Baylor College of Medicine, Houston, Texas 77030 \\ ${ }^{2}$ Department of Biochemistry and Molecular Biology, Drexel University College of Medicine, \\ Philadelphia, Pennsylvania 19102 \\ Correspondence: bslagle@bcm.edu
}

\begin{abstract}
The efficient replication of hepatitis B virus (HBV) requires the HBV regulatory hepatitis B virus $X(\mathrm{HBx})$ protein. The exact contributions of $\mathrm{HBx}$ are not fully understood, in part because of the limitations of the assays used for its study. When HBV replication is driven from a plasmid DNA, the contribution of $\mathrm{HBx}$ is modest. However, there is an absolute requirement for $\mathrm{HBx}$ in assays that recapitulate the infectious virus life cycle. There is much evidence that $\mathrm{HBx}$ can contribute directly to HBV replication by acting on viral promoters embedded within protein coding sequences. In addition, $\mathrm{HBx}$ may also contribute indirectly by modulating cellular pathways to benefit virus replication. Understanding the mechanism(s) of $\mathrm{HBx}$ action during virus replication may provide insight into novel ways to disrupt chronic HBV replication.
\end{abstract}

$T^{\text {he }}$ he replication efficiency of viruses, such as the human hepatitis B virus (HBV), is facilitated by the regulatory proteins they encode. This is particularly important for viruses that infect differentiated cells, such as hepatocytes, which are typically quiescent and may not present an ideal intracellular environment for replication of a DNA virus. Although viruses with large amounts of genetic information may encode multiple regulatory proteins, the $3.2-\mathrm{kb}$ HBV genome encodes a single regulatory protein called hepatitis B virus $\mathrm{X}(\mathrm{HBx})$ (Fig. 1) (reviewed in Seeger et al. 2013). All mammalian hepadnaviruses encode an $\mathrm{X}$ protein, but the avian hepadnaviruses do not. HBx resides in the cytosol and nucleus of HBV-infected cells where it can modulate numerous cellular sig- nal-transduction pathways and interact with various cellular proteins (Fig. 2) (reviewed in Bouchard and Schneider 2004; Neuveut et al. 2010; Wei et al. 2010b). Efforts to define the functions of $\mathrm{HBx}$ during $\mathrm{HBV}$ replication are ongoing. However, HBx has been difficult to study because of limitations of available assays, including the inability of $\mathrm{HBV}$ to infect most cells in culture, the HBV genome structure of overlapping open reading frames, and the difficulties in working with the $17-\mathrm{kDa} \mathrm{HBx}$ protein for which few antibody reagents are available. $\mathrm{Nev}$ ertheless, there is an abundance of data indicating that HBx enhances HBV replication, likely through both direct and indirect mechanisms, and usually by cooperating with the cellular signal-transduction machinery (reviewed in Bou-

Editors: Christoph Seeger and Stephen Locarnin

Additional Perspectives on Hepatitis B and Delta Viruses available at www.perspectivesinmedicine.org

Copyright (C) 2016 Cold Spring Harbor Laboratory Press; all rights reserved; doi: 10.1101/cshperspect.a021402

Cite this article as Cold Spring Harb Perspect Med 2016;6:a021402 
B.L. Slagle and M.J. Bouchard
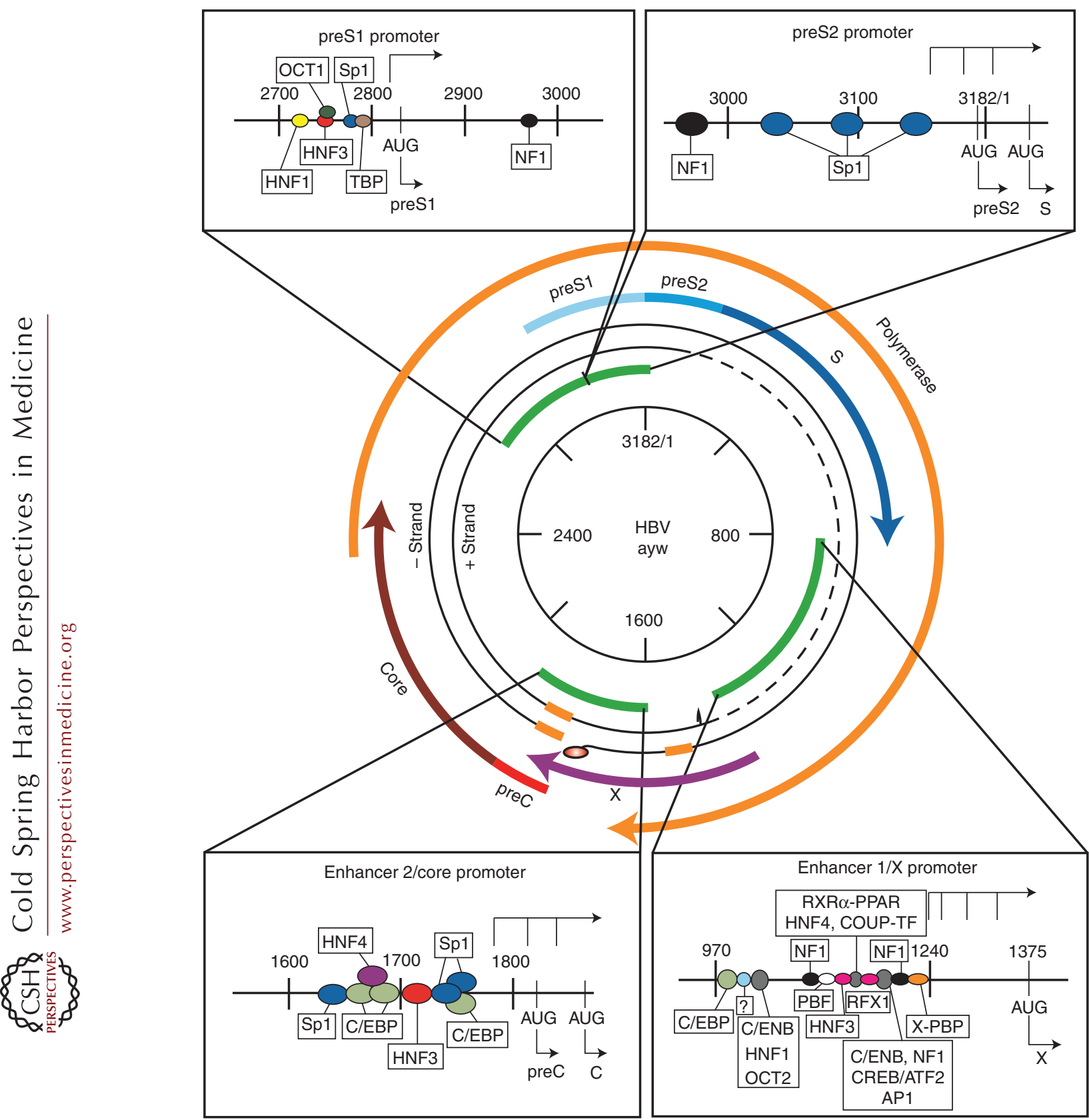

Figure 1. Hepatitis B virus (HBV) genome organization. The HBV genome contains four overlapping open reading frames (ORFs) depicted by the colored arrows. The X ORF (purple) encodes the hepatitis $\mathrm{B}$ virus $\mathrm{X}$ $(\mathrm{HBx})$ regulatory protein. Boxes contain viral regulatory elements: viral promoters ( preS2, preS1, Core, and X) and enhancer elements (ENHI and ENHII), with their position in the genome indicated by green bars. Multiple liver-specific and ubiquitous transcription factors bind to HBV regulatory elements (see text for a detailed description, including abbreviations). 


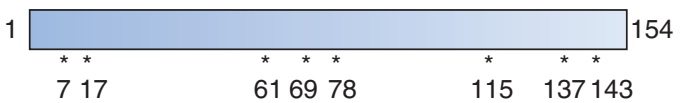

Proteasome binding

Figure 2. Domains of hepatitis B virus X (HBx). The 154-amino-acid (aa) HBx protein is shown, with the asterisks indicating the location of conserved cysteines. Lines below the HBx protein indicate the domain of $\mathrm{HBx}$ that retains the function listed at the left, as described in the text.

chard and Schneider 2004; Neuveut et al. 2010; Wei et al. 2010b). Most studies that have investigated the function of $\mathrm{HBx}$ in the context of $\mathrm{HBV}$ replication have compared viral markers of replication (DNA, RNA, or protein) in liver cells transiently transfected with a plasmid DNA encoding a greater-than-unit length HBV genome capable of expressing HBx (Scaglioni et al. 1997) to the same plasmid DNA that contains a point mutation preventing the expression of $\mathrm{HBx}$ (Melegari et al. 2005). Recently, these approaches have been expanded to studies in cultured primary hepatocytes and in the livers of mice with normal or humanized livers (Clippinger and Bouchard 2008; Clippinger et al. 2009; Gearhart and Bouchard 2010a,b; Tsuge et al. 2010). Cumulatively, these studies have yielded important information on $\mathrm{HBx}$ functions in the context of HBV replication. Continuing studies to define $\mathrm{HBx}$ functions during HBV replication are likely to contribute to the ongoing efforts to design novel therapeutic strategies to interrupt HBV replication and prevent the development of $\mathrm{HBV}$-associated liver diseases.

\section{REQUIREMENT OF HBx IN VIRUS REPLICATION}

The first experiments to investigate a role for $\mathrm{HBx}$ in HBV replication were conducted in plas- midtransfected human liver HuH-7 cells. No significant differences were found in levels of viral proteins, RNA or DNA, when comparing cells transfected with plasmid DNA carrying HBV genomes encoding HBx versus genomes with a mutation that prevented HBx expression, and it was concluded that $\mathrm{HBx}$ was not central to the virus life cycle in vitro (Blum et al. 1992). A similar approach using human hepatoblastoma HepG2 cells showed that HBV genomes encoding $\mathrm{HBx}$ replicated to significantly higher levels than genomes unable to express HBx (Melegari et al. 1998), and that cotransfected plasmids encoding $\mathrm{HBx}$ could restore the $\mathrm{HBx}$-deficient replication to wild-type levels in these cells (Bouchard et al. 2002; Leupin et al. 2005; Tang et al. 2005; Keasler et al. 2007). Interestingly, the effect of HBx is most apparent in HepG2 cells that are quiescent (Bouchard et al. 2002; Leupin et al. 2005; Keasler et al. 2007), a cellular environment similar to the nondividing hepatocyte in vivo. These studies show that HBV can be produced from a plasmid DNA template in transfected cells in the absence of $\mathrm{HBx}$, and that the level of virus replication is increased in the presence of HBx. Similar observations were recently reported in cultured primary rat hepatocytes infected with a recombinant adenovirus containing a wild-type or HBx-deficient copy of the HBV genome (Clippinger et al. 2009). 
Independent animal models similarly conclude a role for HBx in HBV replication in vivo. Mice harboring the HBV genome with an inactivating mutation that prevents HBx expression produced virus particles (Reifenberg et al. 2002; Xu et al. 2002), but the levels of virus were increased by crossbreeding with mice that expressed $\mathrm{HBx}$ (Xu et al. 2002). Hydrodynamic tail vein injection was used to deliver the HBV and HBx-deficient HBV plasmid DNA described above to mouse liver in vivo, and in this model HBx deficiency resulted in a 2-log decrease in viremia that was restored to wildtype levels by coinjection of plasmid DNA encoding HBx (Keasler et al. 2007). Intrahepatic injection of plasmid DNA encoding woodchuck hepatitis B virus (WHV) DNA containing mutations in WHx similarly led to lower levels of replication than wild-type WHV DNA (Zhang et al. 2001). Together, these studies indicate that HBV replication driven from a plasmid template in vivo can occur in the absence of $\mathrm{HBx}$, but that HBx boosts the efficiency of that replication.

The most compelling evidence that $\mathrm{HBx}$ is critical for the virus life cycle comes from two animal models that more closely recapitulate the HBV life cycle. In the first animal model, intrahepatic inoculation of woodchuck hepatitis virus (WHV) genomes capable of expressing woodchuck X protein (WHx) led to replication in woodchuck hosts, whereas WHx-deficient genomes did not replicate and the animals remained susceptible to subsequent viral challenge (Chen et al. 1993; Zoulim et al. 1994). In the second animal model, immunodeficient mice transplanted with human hepatocytes can be infected with HBV (Dandri et al. 2001; Bissig et al. 2010). Virus generated by transfection of HepG2 cells with a plasmid HBV DNA encoding $\mathrm{HBx}$ or a plasmid HBV DNA containing an HBx mutation that prevented HBx expression were used to infect human-liver chimeric mice (Tsuge et al. 2010). Although HBx-proficient HBV particles established viremia in these animals, the HBx-deficient virus did not (Tsuge et al. 2010). Hydrodynamic injection of these mice with $\mathrm{HBx}$-expression plasmid restored the replication of the HBx-deficient virus. This abso- lute requirement of $\mathrm{HBx}$ for $\mathrm{HBV}$ replication was also confirmed in the human HepaRG cell line, which can be directly infected by HBV, and in cultured human hepatocytes (Lucifora et al. 2011). In summary, the requirement for $\mathrm{HBx}$ for $\mathrm{HBV}$ replication is most convincing in model systems that recapitulate the virus life cycle in vivo. In contrast, the impact of $\mathrm{HBx}$ on $\mathrm{HBV}$ replication is modest when virus replication is driven from a plasmid DNA template transfected into established cell lines, which could reflect the constitutive activation of various cellularsignaling pathways in these cell lines that $\mathrm{HBx}$ must activate in normal hepatocytes in vivo (reviewed in Bouchard and Schneider 2004; Seeger et al. 2007).

\section{HBx PROTEIN STRUCTURE}

When the HBV genome was first sequenced and revealed the existence of a novel small open reading frame (ORF), the HBV protein encoded in this ORF was given the name $\mathrm{X}$ protein, or $\mathrm{HBx}$, because its sequence had no homology with known protein motifs that might provide clues to its function (reviewed in Tiollais et al. 1981). Early attempts to define the structure of $\mathrm{HBx}$ and relate HBx structure to its functions relied on a combination of prediction models and activity studies of mutant $\mathrm{HBx}$ proteins (reviewed in Yen 1996). Additional approaches included purification of $\mathrm{HBx}$ from bacterial or insect cell expression systems and analyses of posttranslational modifications of $\mathrm{HBx}$, such as acetylation, phosphorylation, and the formation of disulfide bonds (Lin and Lo 1989; Schek et al. 1991; Urban et al. 1997).

Studies of HBx deletion mutants have identified domains of $\mathrm{HBx}$ responsible for its function (Fig. 3). The transactivation functions of HBx (described below) reside between amino acid (aa) 52-148, whereas aa 1-50 encode a domain that can inhibit HBx activities (Murakami et al. 1994). Further studies defined aa $120-140$ as involved in nuclear transactivation mechanisms, aa 58-119 as involved in signaltransduction activities, and the carboxy-terminal 20 aa as involved in HBx stability (Lizzano et al. 2011). HBx aa 54-70 were later 
HBx and Regulation of Viral Gene Expression

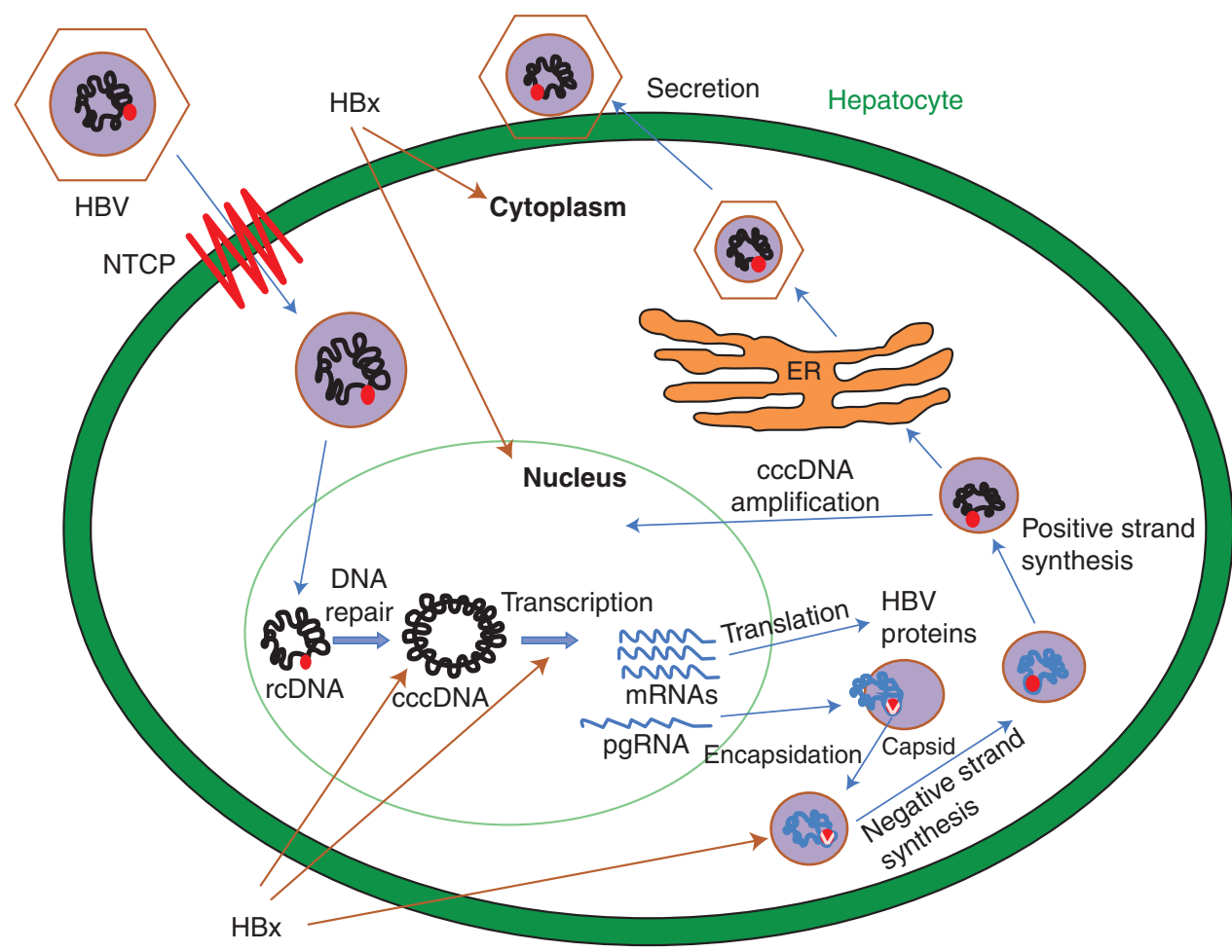

Figure 3. Hepatitis B virus (HBV) life cycle and hepatitis B virus X (HBx). HBV infects hepatocyte by first interacting with its newly identified cell-surface receptor, the sodium-taurocholate cotransporting polypeptide (NTCP; also referred to as SLC10A1) (Yan et al. 2012, 2013; Zhong et al. 2013). The HBV partially doublestranded DNA genome is delivered to the nucleus and converted to a covalently closed circular DNA (cccDNA), which forms a minichromosome and is the source of HBV transcripts. The transcripts are exported to the cytosol for translation, and one of the transcripts, the pregenomic RNA is encapsidated and reversed transcribed to generate the viral DNA genome. Infectious virions are eventually secreted from the cell. HBx is localized to the cytoplasm and nucleus of HBV-infected cells and regulates various stages of HBV replication (arrows). It stimulates HBV transcription both by activating cellular transcription pathways and by affecting epigenetic signals on the cccDNA minichromosome. HBx regulation of cellular signal-transduction pathways also stimulates the HBV reverse transcriptase to facilitate generation of the DNA genome (reviewed in Seeger et al. 2007). ER, Endoplasmic reticulum; rcDNA, relaxed circular DNA; mRNA, messenger RNA; pgRNA, pregenomic RNA.

shown to be essential for HBx localization to mitochondria, whereas aa $75-88$ and $109-$ 131 were shown to aid in the localization of HBx to mitochondria (reviewed in Kumar and Sarkar 2004; Wei et al. 2010b). HBx aa 82-154 are sufficient to mediate binding to proteasome subunits (Zhang et al. 2000), whereas p53 binding is mediated by aa $102-136$ (Lin et al. 1997b). It is important to note, however, that without a defined 3D structure of HBx as a basis for studying mutant $\mathrm{HBx}$ proteins, it remains unclear whether observed effects of the mutant HBx proteins that were analyzed reflected iden- tification of regions of $\mathrm{HBx}$, which are required for specific functions or were caused by disrupting the overall structure of HBx.

Analyses of posttranslational modifications of HBx have identified acetylation, phosphorylation, and disulfide bond formation as potential modifications of $\mathrm{HBx}$, and recent predictive modeling studies have identified putative O-linked glycosylation sites (Lin and Lo 1989; Schek et al. 1991; Urban et al. 1997; Hernandez et al. 2012). However, the significance of observed posttranslational modification of $\mathrm{HBx}$ for its functions remains unclear. Acetylation 
of HBx has only been observed for HBx that is purified from insect cells (Urban et al. 1997), and, with the exception of a recent observation that AKT phosphorylation of HBx on amino acid residue serine 31 may affect the oncogenic potential of HBx (Khattar et al. 2012), the consequence of $\mathrm{HBx}$ phosphorylation during a natural HBV infection remains unclear. Moreover, studies showing disulfide bond formation in samples of purified HBx protein must be interpreted with caution because disulfide bond formation can be an artifact of protein purification methods (Leon et al. 1997; Locker and Griffiths 1999). A majority of HBx is present in the cytosol (Sirma et al. 1998), yet disulfide bond formation in the reducing environment of the cytosol is uncommon (Leon et al. 1997; Locker and Griffiths 1999). Moreover, the results of circular dichroism (CD) spectroscopy studies with a truncated mutant of HBx (containing aa 18-142) in which all cysteines had been deleted or converted to serines suggested that disulfide bond formation between cysteines within the HBx amino acid sequence is not necessary for $\mathrm{HBx}$ structure (de Moura et al. 2005; Lee et al. 2012). However, these conclusions should also be interpreted with caution because the assays used to test the functionality of HBx may not represent actual HBx activities during an HBV infection. Overall, attempts to understand $\mathrm{HBx}$ structure and function with purified $\mathrm{HBx}$ or $\mathrm{HBx}$ mutants have identified regions of $\mathrm{HBx}$ that appear important for particular $\mathrm{HBx}$ activities, but these studies lack clear proof that the mutant proteins retained structures that resemble wild-type $\mathrm{HBx}$.

$\mathrm{HBx}$ has been difficult to purify in large quantities and, to date, $\mathrm{HBx}$ has not been crystalized. Consequently, with the exception of one domain that was cocrystalized with its interacting partner DDB1 (Li et al. 2010), the overall structure of $\mathrm{HBx}$ has been characterized by less precise structural assays, such as CD, fluorescence, and nuclear magnetic resonance (NMR) spectroscopy analyses or predictive in silico bioinformatics approaches (de Moura et al. 2005; van Hemert et al. 2011; Hernandez et al. 2012; Lee et al. 2012). An early attempt to characterize protein secondary structures in
HBx predicted the presences of amino- and carboxy-terminal $\alpha$-helices but otherwise only described patches of hydrophobic and charged residues within the $\mathrm{HBx}$ amino acid sequence (Colgrove et al. 1989). Subsequently, studies using a truncated version of $\mathrm{HBx}$ (aa 18-142) and analyses by CD, NMR, and predictive bioinformatics modeling programs, suggested that the amino-terminal 30 amino acids of the truncated $\mathrm{HBx}$, or potentially the amino-terminal 50 amino acids of wild-type $\mathrm{HBx}$, are unstructured, whereas the carboxy-terminal portion of $\mathrm{HBx}$ is structured (de Moura et al. 2005; Lee et al. 2012). These studies did not define the exact structures present in the carboxyterminal portion of $\mathrm{HBx}$. More sophisticated computer-modeling programs have predicted $\mathrm{HBx}$ structures used for in silico modeling of the overall structure of HBx (van Hemert et al. 2011; Hernandez et al. 2012). One study used this technique to model HBx structure in combination with an analysis of conserved HBx sequences in different $\mathrm{HBV}$ isolates that might indicate sites of phosphorylation or modification by $O$-linked glycosylation with $N$-acetylglucosamine (O-GlcNac) via a cytosolic glycosylation pathway (Hernandez et al. 2012). The results of this study predicted that there are numerous $\alpha$-helical structures in the central portion of $\mathrm{HBx}$, that serine 25 and 41 and threonine 81 of HBx are exposed on the surface of HBx, and that these aa residues are contained within conserved phosphorylation or glycosylation sequences. Whether this in silico prediction of phosphorylated and glycosylated sites on $\mathrm{HBx}$ accurately reflect in vivo modifications of $\mathrm{HBx}$ awaits further confirmative studies. Of note is that the in silico study did not predict phosphorylation of HBx serine 31, which was identified as a site of AKT phosphorylation in another study (Khattar et al. 2012); however, the in silico modeling system focused on $\mathrm{HBx}$ aa residues that are conserved in multiple $\mathrm{HBV}$ genotypes, and the $\mathrm{HBx}$ serine 31 in the previous study is not conserved (Hernandez et al. 2012). In silico modeling was also used to compare the predicted 3D structure of $\mathrm{HBx}$ with cellular proteins. This analysis suggested that HBx has considerable structural homology 
with a DNA glycosylase (van Hemert et al. 2011). Support for the accuracy of the structure generated by this in silico modeling method was provided by comparison to a portion of $\mathrm{HBx}$ that had been previously cocrystallized with the cellular damaged DNA-binding protein 1 (DDB1) (Li et al. 2010). In this cocrystallization study, a region of $\mathrm{HBx}$ was shown to contain a three-turn $\alpha$-helical structure that permits interaction with DDB1, an important adaptor protein for the Cullin 4 E3 ligase complex. The three-turn $\alpha$-helical motif is also found in many cellular proteins that bind to the same region of DDB1 to which $\mathrm{HBx}$ binds. Importantly, the in silico modeling approach of the $3 \mathrm{D}$ structure of $\mathrm{HBx}$ and the crystal structure characterized in HBx-DDB1 cocrystals were similar for the region common to both studies. Although in silico docking of HBx to DNA supported the notion that its structure is similar to a DNA glycosylase, $\mathrm{HBx}$ does not bind to double-stranded DNA in vivo, and whether it can bind to single-stranded DNA in an authentic HBV infection remains unclear (reviewed in Bouchard and Schneider 2004; Wei et al. 2010b). Consequently, although the in silico generation of a $3 \mathrm{D}$ structure of $\mathrm{HBx}$ provides a platform for targeted mutagenic studies of $\mathrm{HBx}$ to interrogate structure-function relationships, precisely how this putative DNA glycosylase structure is related to $\mathrm{HBx}$ functions remains to be determined.

\section{HBx ACTS ON HBV ENHANCERS AND PROMOTERS}

The generation of HBV transcripts encoding the viral precore, core, envelope, polymerase, and HBx protein is controlled by four transcription promoters and two enhancers (Fig. 1) (reviewed in Seeger et al. 2013). Transcription factors that bind $\mathrm{HBV}$ promoters and enhancers include hepatocyte nuclear factor (HNF) 1, HNF3 (Fox A), HNF4 $\alpha$, CCAAT-enhancer-binding protein $(\mathrm{C} / \mathrm{EBP}) 1$, activating transcription factor (ATF), cAMP response element-binding protein (CREB), SP1, Oct1, and peroxisome proliferator-activated receptor (PPAR) $\gamma$ (reviewed in Seeger et al. 2007). Enhancer I (ENHI) con- tains binding sequences for transcription factors that are expressed in many cell types, whereas ENHII contains recognition sequences for hepatocyte-specific transcription factors (reviewed in Seeger et al. 2007). Consequently, the activity level of HBV enhancers and their stimulation of HBV promoters can vary depending on the cell types used to assess the activity of these elements. Interestingly, in vivo studies in mice have shown that the activity of the HBV enhancers and their ability to stimulate transcription from HBV promoters is significantly greater in vivo than in cell lines (Du et al. 2008). In these studies, the activity of each of the four HBV transcription promoters linked to ENHI or ENHII and a luciferase reporter was tested in transfected cells versus following hydrodynamic delivery of the same plasmids to mouse liver in vivo; the in vivo level of luciferase was monitored by bioluminescence imaging and compared to luciferase levels in the transfected Hepa1-6 mouse hepatoma cells. In contrast to the modest strength of these viral regulatory elements in transfected mouse Hepa1-6 cells in vivo, the enhancers stimulated the promoters by 17 - to 180 -fold (ENHI) and 14- to 140-fold (ENHII) (Du et al. 2008). Importantly, these results also suggest that previous studies that have relied on assays in cell lines may have underestimated $\mathrm{HBV}$ protein levels that are present in a natural HBV infection.

Although transcription from HBV promoters and enhancers is not absolutely dependent on $\mathrm{HBx}$ expression, $\mathrm{HBx}$ can stimulate transcription of both HBV and cellular transcription-regulatory elements in various cell lines and in vivo in hepatocytes (reviewed in Bouchard and Schneider 2004; Gearhart and Bouchard 2010b; Wei et al. 2010b). HBx has sometimes been described as a "weak" transactivator, but this description is inconsistent with the impact of $\mathrm{HBx}$ on expression of HBV transcripts and the highly efficient HBV replication observed in vivo. One probable explanation is that liver-enriched transcription factors that are activated by $\mathrm{HBx}$ in vivo in differentiated hepatocytes are present at greatly altered levels in dedifferentiated cell lines (Schrem et al. 2002, 2004) that are often used to analyze HBx trans- 
activator functions, and the two- to fourfold transactivation observed for HBx in cell lines may represent only a portion of its function in vivo.

HBx localization to the nucleus and cytosol has been linked to its transcriptional activity, and nuclear or cytosolic HBx can affect different transcription factors (reviewed in Bouchard and Schneider 2004; Benhenda et al. 2009; Wei et al. 2010b). For example, one study showed that nuclear localized HBx stimulates ENHI of HBV (Doria et al. 1995). HBx does not bind to DNA, and HBx activation of RNA polymerase (pol) I-, pol II-, and pol III-dependent promoters has been linked to a direct interaction with some transcription factors as well as stimulation of cellular signal-transduction pathways that regulate transcription (Aufiero and Schneider 1990; Kwee et al. 1992; Wang et al. 1995, 1997, 1998). HBx stimulation of cellular signal-transduction proteins, including Pyk2 and Src kinases, Ras, Raf, and the mitogen-activated protein kinases (MAPK), extracellular signal-regulated kinase (ERK), amino-terminal c-jun kinase (JNK), and p38MAPK, has been linked to HBx activation of various transcription factors (Benn and Schneider 1994; Benn et al. 1996; Andrisani and Barnabas 1999; Klein et al. 1999; Tarn et al. 2001, 2002; Bouchard et al. 2002, 2003; Wang et al. 2008). Transcription factors that are activated by $\mathrm{HBx}$ include nuclear factor (NF)- $\mathrm{B}$, activator protein (AP) 1, $\mathrm{AP} 2, \mathrm{C} / \mathrm{EBP} \alpha, \mathrm{ATF} / \mathrm{CREB}, \mathrm{SP} 1$, signal transducer and activator of transcription (STAT)3, hypoxia inducible factor (HIF) $1 \alpha$, nuclear factor of activated T cells (NFAT), and E2F (Lucito and Schneider 1992; Lucito 1993; Doria et al. 1995; Williams and Andrisani 1995; Benn et al. 1996; Su and Schneider 1996; Lara-Pezzi et al. 1998; Lee et al. 1998; Tarn et al. 2001, 2002; Waris et al. 2001; Yoo et al. 2003; Wang et al. 2004, 2008). HBx can directly associate with components of the basal transcriptional machinery, including transcription factor (TF)IIB, TFIIH, and TATA-binding protein (TBP) and with transcription factors, such as CREB/ATF, $\mathrm{C} / \mathrm{EBP} \alpha, \mathrm{ATF} 3, \mathrm{SMAD} 4$, and sterol regulatory element-binding protein (SREBP)1, to increase their activity or affinity for their DNA- binding sites (Williams and Andrisani 1995; Haviv et al. 1996, 1998; Lin et al. 1997a; Choi et al. 1999; Perini et al. 1999; Lee et al. 2001a; Waris et al. 2001; Kim et al. 2007a). It is important to note, however, that many studies of $\mathrm{HBx}$ interactions with transcription factors required the use of in vitro protein expression systems or cells in which $\mathrm{HBx}$ and a specific transcription factor were overexpressed. Although these types of studies provide insights into $\mathrm{HBx}$ activities, confirmation of the interaction of $\mathrm{HBx}$ with specific transcription factors in the context of a natural $\mathrm{HBV}$ infection is needed to provide definitive proof of the relevance of these interactions.

The ability of HBx to activate cellular transcription pathways has been assessed in various cell lines, including both liver-derived cell lines, such as HepG2, Huh7, and AML12 cells, and non-liver-derived cell lines, such as NIH3T3, HeLa, and Chang cells (reviewed in Bouchard and Schneider 2004; Benhenda et al. 2009; Wei et al. 2010b). Although originally thought to be a liver cell line, careful analysis of Chang cells have confirmed that these cells are likely a HeLa cell contaminant (Nelson-Rees and Flandermeyer 1976). These assays of HBx activities in different cell lines have demonstrated that $\mathrm{HBx}$ modulation of transcription promoters and transcription factors can vary in different experimental systems, complicating the evaluation of the precise transcription factors and transcription-signaling pathways that are regulated by HBx during an authentic HBV infection. Moreover, because the assessment of $\mathrm{HBx}$ stimulation of transcription has often relied on transient transfections of transcription-reporter plasmids, it remains uncertain whether these studies are directly relevant for $\mathrm{HBx}$ effects on endogenous cellular promoters and enhancers (reviewed in Bouchard and Schneider 2004; Benhenda et al. 2009; Wei et al. 2010b). Recent studies have begun to directly assess HBx effects on transcription factor localization to cellular endogenous promoters, and $\mathrm{HBx}$ was recently shown to increase the recruitment of CBP / p300 to cellular interleukin (IL)-8 and PCNA promoters (Cougot et al. 2007). Similar types of studies will be essential for confirming that the 
many transcription factors that have been reported to be activated by $\mathrm{HBx}$, and possibly affect expression of endogenous cellular genes, do, in fact, influence transcription from endogenous cellular transcription promoters and enhancers. Although studies that have used cDNA-microarray technologies, chromatin immunoprecipitation (ChIP) methods, or serial analysis of gene expression (SAGE), have clearly shown that $\mathrm{HBx}$ can regulate expression of endogenous genes in hepatocytes (Wu et al. 2002; Zhang et al. 2009), a direct correlation of these studies with specific transcription factors activated by $\mathrm{HBx}$ in the studies described above awaits further analyses. Importantly, $\mathrm{HBx}$ has been shown to stimulate transcription in vivo in hepatocytes. When mice that express a reporter gene controlled by the human immunodeficiency virus (HIV) long terminal repeat (LTR) were crossed with $\mathrm{HBx}$-transgenic mice that express $\mathrm{HBx}$ in hepatocytes, transcription of the reporter was increased (Balsano et al. 1994). Moreover, another study reported an increase in $\mathrm{HBV}$ core promoter activity by $\mathrm{HBx}$ when $\mathrm{HBV}$ - and $\mathrm{HBx}$-transgenic mice were crossed (Reifenberg et al. 1999b). Although these results confirm that $\mathrm{HBx}$ activates transcription factors in hepatocytes, the mechanisms that underlie this $\mathrm{HBx}$ activity and the precise transcription factors that are stimulated in authentic hepatocytes remain incompletely defined.

Recently, HBx has been shown to affect epigenetic-signaling mechanisms (reviewed in Andrisani 2013). HBx can up-regulate expression of DNA methyltransferases DNMT1, DNMT3A1, and DNMT3A2 causing an overall increase in their cellular activity (Qiu et al. 2014). This HBx-induced increase in DNA methyltransferase activity has been linked to decreased expression of E-cadherin and the tumor suppressor p16 (Lee et al. 2005; Jung et al. 2007; Park et al. 2007). Of particular importance to $\mathrm{HBV}$ replication, $\mathrm{HBx}$ has also been shown to regulate epigenetic signatures on HBV covalently closed circular DNA (cccDNA) minichromosomes (described below), although, in that case, $\mathrm{HBx}$ is thought to relieve negative regulation of the cccDNA template, leading to increased tran- scription (Benhenda et al. 2013). HBx regulation of epigenetic signals provides an additional means for $\mathrm{HBx}$ regulation of both cellular and HBV transcription in HBV-infected cells and likely contributes to the many transcriptional effects that have been linked to HBx expression.

\section{HBX AND cccDNA}

Soon after infection of a permissive cell, HBV virion DNA, also known as relaxed circular DNA (rcDNA), is converted to cccDNA, which serves as the template for viral transcription (Tuttleman et al. 1986). Two laboratories have reported that conversion of rcDNA to cccDNA occurs in the absence of $\mathrm{HBx}$ expression indicating that $\mathrm{HBx}$ is not required for this important step in virus replication (Chou et al. 2005; Lucifora et al. 2011). Mutations in the HBV reverse transcriptase do not affect cccDNA formation, and it has been concluded that cellular enzymes are responsible for converting rcDNA into cccDNA (Moraleda et al. 1997; Sohn et al. 2009).

HBV cccDNA is organized as a minichromosome with regularly spaced nucleosomes containing histone and nonhistone proteins (Bock et al. 1994; Newbold et al. 1995). Two populations of cccDNA containing a full or half complement of nucleosomes have been observed, suggesting that cccDNA is dynamic and subject to transcriptional regulation (Newbold et al. 1995). Although cellular chromatin shows a nucleosome repeat of 200 base pairs (bp), HBV cccDNA has 180 bp repeat units (Bock et al. 1994) and duck hepatitis B virus cccDNA a repeat of $150 \mathrm{bp}$ (Newbold et al. 1995). The significance of the more compact viral cccDNA is unknown. cccDNA is present in the nucleus of infected cells at 1 to 50 copies per cell (Newbold et al. 1995; Moraleda et al. 1997; Zoulim 2005; Wang et al. 2011), and is stable throughout the lifespan of the hepatocyte. Antiviral therapy does not eliminate cccDNA, and understanding how the virus regulates expression from the cccDNA template may provide insight into ways to silence cccDNA and prevent reactivation of an inactive or resolved hepatitis B virus infection in which cccDNA is still present. 
The protein composition of cccDNA was determined by antibody reactivity to purified nucleocapsid complexes. These studies established that $\mathrm{HBcAg}$ is a regular component of the cccDNA, as are cellular histones H2A, H2B, H3, and H4 (Bock et al. 2001). Other studies used the sensitive ChIP assay to immunoprecipitate (IP) proteins bound to the cccDNA complex, followed by polymerase chain reaction (PCR) detection of cccDNA to which the protein was bound. Using this approach, several positive regulators of gene transcription were shown to be recruited to cccDNA, including histone acetyltransferase CBP, p300, PCAF/ GCN5 (Pollicino et al. 2006; Cougot et al. 2007; Belloni et al. 2009), and transcription factor CREB (Cougot et al. 2007). The HBV regulatory $\mathrm{HBx}$ protein was also recruited to cccDNA (Belloni et al. 2009), a finding consistent with its proposed role of increasing HBV transcription at the level of cccDNA (Lucifora et al. 2011). Also present on the cccDNA are negative regulators of transcription, histone deacetylase 1 (HDAC1) (Pollicino et al. 2006), hSIRT1 (Belloni et al. 2009), protein phosphatase 1 (PP1) (Cougot et al. 2012), and arginine methyltransferase 1 (PRMTI) (Benhenda et al. 2013).

Gene expression from chromatin is regulated, in part, through histone modification. The amino-terminal tails of the four histones present on the nucleosome surface may be modified by several different enzyme-catalyzed, posttranslational modifications of select amino acids. These modifications include lysine acetylation, lysine and arginine methylation, serine phosphorylation, and attachment of the ubiquitin and small ubiquitin-like modifier (SUMO). Evidence indicates that $\mathrm{HBx}$ is associated with epigenetic regulation of cccDNA transcription. The kinetics of HBx binding to the cccDNA complex closely follows that of acetylated $\mathrm{H} 3$, a marker of transcriptionally active chromatin and HBV transcription (Belloni et al. 2009). In addition, when cccDNA is formed in the absence of $\mathrm{HBx}$, it is transcriptionally silent (Pollicino et al. 2006; Belloni et al. 2009; Lucifora et al. 2011) and contains nonacetylated histones, histone deactylases HDAC1 and hSirt1
(Pollicino et al. 2006; Belloni et al. 2009), and methylated H4 (Benhenda et al. 2013). When formed in the presence of $\mathrm{HBx}$, the cccDNA is enriched for proteins associated with transcription, such as acetylated $\mathrm{H} 3 / \mathrm{H} 4$ and acetyltransferase p300) (Pollicino et al. 2006; Belloni et al. 2009) and hypomethylated H4 (Benhenda et al. 2013). Finally, the addition of HDAC inhibitors to HBV-infected cells blocks the recruitment of HDAC1 to cccDNA, and leads to increased $\mathrm{HBV}$ transcription (Pollicino et al. 2006)

The mechanism by which $\mathrm{HBx}$ acts on the cccDNA template is complex. In one study, the interaction of $\mathrm{HBx}$ with PP1 was associated with a longer half-life of CREB phosphorylation, a positive regulator of transcription (Cougot et al. 2012). Alternatively, the interaction of HBx with the methyltransferase PRMT1 is thought to inhibit methylation of $\mathrm{H} 4$ and enhance transcription (Benhenda et al. 2013). Overexpressed PRMT1 inhibited HBV transcription from cccDNA, and this was reversed by the expression of $\mathrm{HBx}$ (Benhenda et al. 2013). Because HBx does not bind DNA directly, its interaction with cccDNA must be mediated by another HBV or cellular protein. Interestingly, the cccDNA remains transcriptionally silent in cells that express a mutant $\mathrm{HBx}$ protein that is unable to bind cellular DDB1 (Lucifora et al. 2011; van Breugel et al. 2012), suggesting a role for the HBx-DDB1 interaction in the regulation of $\mathrm{HBV}$ transcription from the cccDNA template. This is an attractive idea, because DDB1 is a known DNA-binding protein. $\mathrm{HBx}$ mutant proteins that do not bind DDB1 are unable to restore $\mathrm{HBx}$-deficient replication in the HBV plasmid replication assay, and the defect occurs at the level of viral transcription (Leupin et al. 2005; Hodgson et al. 2012).

The study of HBx function on a cccDNA template is thought to be more biologically relevant than studies on plasmid DNA. However, the magnitude of the effect of $\mathrm{HBx}$ on transcription of the largest HBV mRNA from cccDNA is less than threefold (Belloni et al. 2009), indicating that limitations remain for this model system of $\mathrm{HBx}$ function. 


\section{HBx EFFECT(S) ON CELLULAR PATHWAYS}

Viruses replicate efficiently in cells, in part by altering the physiology of infected cells to favor viral replication. HBx can stimulate many cellular signal-transduction pathways, and this has been linked to efficient HBV replication (reviewed in Bouchard and Schneider 2004; Benhenda et al. 2009; Wei et al. 2010b).

\section{HBx and Calcium-Signaling Pathways}

HBx effects on cellular signal-transduction pathways can involve direct interactions between $\mathrm{HBx}$ and cellular signaling proteins and the induction of cellular signal-transduction cascades through modulation of cellular calcium $\left(\mathrm{Ca}^{2+}\right)$ and reactive oxygen species (ROS) levels (Waris et al. 2001; Bouchard et al. 2002). HBx-induced changes in cytosolic $\mathrm{Ca}^{2+}$ and ROS levels have been measured in various liver cell lines (Waris et al. 2001; Chami et al. 2003; Yang and Bouchard 2012). HBx elevation of cytosolic $\mathrm{Ca}^{2+}$ activates Pyk2 and Src kinases, Ras, Raf, and mitogenactivated protein kinases (MAPK), STAT3, and various other transcription factors (Bouchard et al. 2002; Tarn et al. 2002). HBx elevation of cellular ROS levels has been linked to activation of NF- $\kappa B$ and STAT3 (Waris et al. 2001). HBx regulation of cytosolic $\mathrm{Ca}^{2+}$ stimulates $\mathrm{HBV}$ replication in HepG2 cells and cultured primary rat hepatocytes (Bouchard et al. 2002; Gearhart and Bouchard 2010a). HBx regulation of cytosolic $\mathrm{Ca}^{2+}$ can be blocked by inhibitors of the mitochondrial permeability transition pore (MPTP) (Bouchard et al. 2002; Gearhart and Bouchard 2010a). The possible role of outer mitochondrial membrane protein voltage-dependent anion channel (VDAC) in functions of the MPTP, and the reported interaction of $\mathrm{HBx}$ and VDAC, suggest that $\mathrm{HBx}$ regulation of mitochondrial $\mathrm{Ca}^{2+}$ signaling may affect its elevation of cytosolic $\mathrm{Ca}^{2+}$ levels (Rahmani et al. 2000). This notion was recently supported by studies linking $\mathrm{HBx}$ regulation of cytosolic $\mathrm{Ca}^{2+}$ levels to store-operated calcium entry (SOCE) mechanisms in HepG2 cells (Yang and Bouchard 2012). In these studies, HBx ele- vation of cytosolic $\mathrm{Ca}^{2+}$ entry required active SOCE channels. Significantly, mitochondria are known to participate in enhanced SOCE channel activity, and HBx elevation of cytosolic $\mathrm{Ca}^{2+}$ levels required metabolically active mitochondria (Glitsch et al. 2002; Yang and Bouchard 2012). Interestingly, recent studies have also suggested that mitochondrial antiviral-signaling proteins (MAVS) could be an additional target of HBx (Wei et al. 2010a), and it is possible that mitochondria serve as cellular hubs for some $\mathrm{HBx}$ activities.

\section{HBx and Apoptosis}

Several studies have shown an effect of HBx on cellular apoptosis. HBx can induce apoptosis, sensitize cells to proapoptotic stimuli or prevent apoptosis, depending on the experimental system used to analyze these HBx effects (reviewed in Rawat et al. 2012). Some studies have shown enhanced apoptosis in hepatocytes in mice expressing $\mathrm{HBx}$, whereas others have not. $\mathrm{HBx}$ can block cell death mediated by tumor necrosis factor (TNF)- $\alpha$, Fas, p53, or transforming growth factor (TGF)- $\beta$ in some cell lines while promoting apoptosis in other cell lines (Elmore et al. 1997; Kim et al. 1998; Bergametti et al. 1999; Shih et al. 2000; Diao et al. 2001; Lee et al. 2001b; Pan et al. 2001; Shirakata and Koike 2003). In one study, the proapoptotic activity of $\mathrm{HBx}$ was through HBx inactivation of c-FLIP, a protein that protects against TNF- $\alpha$ and Fasmediated apoptosis. However, overexpression of cFLIP did not fully block apoptosis stimulated by $\mathrm{HBx}$, and it is unlikely that cFLIP is the only means through which HBx modulates apoptosis (Kim and Seong 2003). The recognition that $\mathrm{HBx}$ interacts with VDAC suggests a possible mechanism of $\mathrm{HBx}$-induced modulation of apoptotic pathways, although this association could be either pro- or antiapoptotic (Rahmani et al. 2000). HBx can induce mitochondrial aggregation and cytochrome $c$ release, which could be linked to induction of apoptosis (Takada et al. 1999; Kim et al. 2007b). HBx is antiapoptotic in cultured primary rat hepatocytes; this effect was linked to $\mathrm{HBx}$ activation of NF-кB (Clippinger et al. 2009). HBx 
became proapoptotic in cultured primary rat hepatocytes when the activity of NF- $\mathrm{KB}$ was blocked, suggesting that $\mathrm{HBx}$ can be either pro- or antiapoptotic depending on the status of NF-kB.

\section{HBx and the Cell Cycle}

Many viruses encode proteins that can stimulate the cell cycle, and the need for this function for $\mathrm{HBV}$ is suggested by the fact that HBV infects nondividing hepatocytes. Indeed, $\mathrm{HBx}$ can regulate cell proliferation, although the precise impact of HBx has varied in different experimental systems. HBx can cause cells to enter the cell cycle and stall at the $G_{1} / S$ border or progress more rapidly through the cell cycle, depending on the experimental system used to analyze this HBx activity (reviewed in Madden and Slagle 2001; Casciano et al. 2012). HBx had different effects in differentiated and dedifferentiated hepatocytic cells that were derived from the same parental cell line. The differentiated cells displayed $\mathrm{HBx}$-dependent $\mathrm{G}_{1}, \mathrm{~S}$, and $\mathrm{G}_{2} / \mathrm{M}$ progression; the dedifferentiated cells displayed $\mathrm{HBx}$-dependent $\mathrm{G}_{1}$ and $\mathrm{S}$ phase entry but paused in S phase (Lee et al. 2002). HBx caused cultured primary rat hepatocytes to exit $\mathrm{G}_{0}$ but stall in $\mathrm{G}_{1}$; this $\mathrm{HBx}$ effect was directly linked to $\mathrm{HBx}$ stimulation of HBV replication in these cells (Gearhart and Bouchard 2010a,b). In cultured primary rat hepatocytes, $\mathrm{HBx}$ decreased expression of the cell-cycle inhibitor proteins, p15 and p16, which block entrance into $G_{1}$, but elevated levels of the cell-cycle inhibitor proteins, p21 and p27, which have an activating role in $G_{1}$ but inhibit progression into $S$ phase. $\mathrm{HBx}$ also increased the level of cyclin D1 and the activity of cyclin-dependent kinase $4(\mathrm{CDK} 4)$, proteins important in $\mathrm{G}_{1}$ progression, but did not affect levels of the $S$ phase proteins and inhibited CDK2 activity, which is required for progression beyond $G_{1}$ (Gearhart and Bouchard 2010a,b). Overall, these studies showed that, for efficient HBV replication, hepatocytes must exit $\mathrm{G}_{0}$ and enter $G_{1}$, but then remain in the $G_{1}$ phase of the cell cycle. Similar HBx effects on cell proliferation pathways were observed in human hepatocytes
(Gearhart and Bouchard 2011). Three groups used HBx transgenic mice to analyze HBx effects on hepatocyte regeneration; two groups showed that $\mathrm{HBx}$ blocked liver regeneration (Tralhao et al. 2002; Wu et al. 2006), whereas one group showed that HBx caused cell-cycle entry of a subpopulation of hepatocytes (Hodgson et al. 2008).

\section{HBx and DDB1}

$\mathrm{HBx}$ can also regulate responses to and repair of damaged DNA. One HBx-binding partner, the damaged DNA-binding protein 1 (DDB1) (Lee et al. 1995; Sitterlin et al. 1997) is an adaptor protein for the Cullin 4-DDB1 E3 ligase. DDB1 functions, in part, through its interactions with DDB1 cullin adaptor factors (DCAFs) that bind to a specific location on the DDB1 molecule. DCAF proteins recruit substrates for E3-mediated ubiquitination and degradation (reviewed in McCall et al. 2005; Lee and Zhou 2007; O'Connell and Harper 2007). Because $\mathrm{HBx}$ shares a 16-amino acid motif with these DCAFs (Keasler and Slagle 2008; Li et al. 2010), it is possible that $\mathrm{HBx}$ may displace one or more DCAFs from the Cul4/DDB1 complex, thereby altering the spectrum of downstream cellular proteins targeted for degradation. Studies from two laboratories reported that $\mathrm{HBx}$ can displace at least two different DCAFs from DDB1 in transfected cells in culture (Bergametti et al. 2002; Li et al. 2010), although the downstream targets affected by this displacement are not known.

There is evidence that the binding of $\mathrm{HBx}$ (or WHx) to DDB1 is important in virus replication. WHV is highly homologous to $\mathrm{HBV}$ and encodes an $\mathrm{X}$ protein (WHx) that is similar to $\mathrm{HBx}$ and required for WHV replication. Viremia was not observed when woodchucks were infected with the WHV engineered to encode WHx that could not bind to DDB1 (Sitterlin et al. 1997). In woodchucks infected with a WHV mutant that encoded WHx, which could not bind DDB1, the few woodchucks that developed viremia were found to have reverted to wild-type WHx, suggesting that the authentic $\mathrm{WHx}-\mathrm{DDB} 1$ interaction was essential for virus 
replication in vivo. A similar conclusion was reached in studies using the HBV plasmid replication assay in HepG2 cells; HBx-deficient HBV replication could be restored by wildtype $\mathrm{HBx}$, but not by $\mathrm{HBx}$ mutants that were unable to bind DDB1 (Leupin et al. 2005; Hodgson et al. 2012). The HBx-DDB1 interaction may be important for HBV transcription (described above) or for the cellular response to damaged DNA (Becker et al. 1998), but other possible functions should be considered. Several viruses encode proteins that bind to DDB1 as part of their strategy for virus replication (reviewed in Barry and Früh 2006; Dehart and Planelles 2008). The Paramyxovirus Simian Virus 5 (SV5) regulatory $\mathrm{V}$ protein binds to DDB1 (Lin et al. 1998) and redirects the E3 ligase to ubiquitinate and degrade STAT1, thereby inactivating host interferon signaling (Precious et al. 2005). The murine herpesvirus 68 interacts with the Cul4A-DDB1 ${ }^{\mathrm{COP} 9}$ complex to activate the DNA damage signal (Liang et al. 2006). The HIV-1 regulatory Vpr protein binds DDB1 indirectly (through Cul4A-DDB1 ${ }^{\mathrm{DCAF1}}$ ), and redirects DDB1 to induce $\mathrm{G}_{2}$ cell-cycle arrest (Schrofelbauer et al. 2007). The DDB1 function targeted by HBx is an important unanswered question.

\section{$\mathrm{HBx}$ and Cancer}

Certain properties of $\mathrm{HBx}$, such as its ability to regulate cellular signal-transduction pathways, affect cell-cycle progression, and activate damaged DNA responses, raise the possibility that $\mathrm{HBx}$ may contribute to the development of HBV-associated hepatocellular carcinoma (HCC). A chronic HBV infection remains the most common cause of HCC (Mittal and ElSerag 2013), and the inflammatory response to $\mathrm{HBV}$ infection and viral integration are clearly central to any model of HBV-associated HCC. However, there is also evidence that HBx can contribute to the carcinogenesis process (reviewed in Riviere et al. 2014). Studies in $\mathrm{HBx}$ transgenic mice have yielded complex results. Some lineages of HBx mice develop HCC (Kim et al. 1991; Yu et al. 1999; Wu et al. 2006), whereas other lineages do not (Lee et al. 1990; Billet et al.
1995; Reifenberg et al. 1999a; Klein et al. 2003). A close examination of the studies showing HCC revealed complications of spontaneous HCC in nontransgenic control mice (Kim et al. 1991), the presence of steatosis (Wu et al 2006), or a possible misdiagnosis of biliary cysts rather than HCC (Dirsch et al. 2004). Despite the paucity of data on $\mathrm{HBx}$ as an oncogene in vivo, there is agreement that $\mathrm{HBx}$ can cooperate with various HCC risk factors to further increase the incidence of HCC (Dandri et al. 1996; Slagle et al. 1996; Klein et al. 2003; Zhu et al. 2004; Keasler et al. 2006; Wang et al. 2012). Precisely how HBx effects HCC development in the context of a HBV replication awaits the development of model systems in which this process can be studied during a natural HBV infection and remains an area of active and important investigation.

\section{The Multifunctional Nature of $\mathrm{HBx}$}

Considering the small size of its genome, HBV must rely heavily on the host cell to accomplish its life cycle (Fig. 2). HBx is the only regulatory protein encoded in the HBV genome and participates in generating a cellular environment that is conducive to HBV replication; thus, it is not surprising that $\mathrm{HBx}$ has been assigned numerous functions (reviewed in Benhenda et al. 2009; Wei et al. 2010b; Lucifora and Protzer 2012). HBx has been implicated in viral and cellular transcription, DNA repair, cellular proliferation, autophagy/mitophagy, and apoptosis (Tian et al. 2011, and as described above). The ability of HBx to reside in different subcellular compartments is one important feature of its multifunctional role during $\mathrm{HBV}$ replication. Cytoplasmic $\mathrm{HBx}$ transactivates cellular-signaling pathways (e.g., MAPK, JNK, p38, JAK-STAT, pathways, etc.) (Klein and Schneider 1997; Tarn et al. 2002), and nuclear HBx was reported to interact with components of the basal transcription machinery (RPB5, TFIIB, TBP) (Cheong et al. 1995; Qadri et al. 1995; Haviv et al. 1996) and specific transcription factors to regulate host genes (Lucito and Schneider 1992; Lucito 1993). In addition, the ability of HBx to interact with many different cellular partners could 
mediate its pleiotropic effects (reviewed in Ganem and Schneider 2001; Seeger et al. 2013). A comprehensive description of all cellular proteins that interact with $\mathrm{HBx}$ and all cellular-signaling pathways that are modulated by $\mathrm{HBx}$ is beyond the scope of this review; the reader is referred to reviews that have extensively described $\mathrm{HBx}$ interaction partners and $\mathrm{HBx}$ functions (Benhenda et al. 2009; Wei et al. 2010b).

Although the many functions ascribed to $\mathrm{HBx}$ have raised the question of how one protein could have so many effects, it is important to note that a broad array of activities in viral regulatory proteins is neither unexpected nor unprecedented. Some confusion regarding $\mathrm{HBx}$ effects has probably been caused by the myriad of experimental systems and HBx expression methods that have been used to study $\mathrm{HBx}$ functions. For example, $\mathrm{HBx}$ activities have been analyzed with $\mathrm{HBx}$ that is expressed alone and in the context of HBV replication and in cell lines of liver and nonliver origin, in cultured primary human, mouse, and rat hepatocytes, and in hepatocytes in the livers of normal mice and mice with humanized livers (reviewed in Bouchard and Schneider 2004; Benhenda et al. 2009; Wei et al. 2010b). Because these studies have often analyzed the end point of complex cellular signal-transduction pathways, observed $\mathrm{HBx}$ effects likely represent $\mathrm{HBx}$ activities that are specific to a particular cellular environment. The results of these many studies, and recent attempts to identify fundamental HBx activities, suggest the pleiotropic effects of $\mathrm{HBx}$ in various experimental systems may be controlled by a few fundamental $\mathrm{HBx}$ activities that can ultimately have different effects in different experimental systems. A key remaining area of investigation is to identify $\mathrm{HBx}$ activities in the context of HBV replication in biologically relevant in vivo and ex vivo primary hepatocyte systems. Although overexpression of $\mathrm{HBx}$ has also been considered as a complicating factor that could affect HBx activities observed in some studies, the precise level of HBx expression during HBV replication is unknown. Recent studies that have analyzed the in vivo activity of HBV promoters and enhancers suggest that the levels of HBx in an authentic infection may have been underestimated (Du et al. 2008). $\mathrm{HBx}$ expression has been reported as being low during HBV replication, but these conclusions were based on comparison to expression of other HBV proteins with antibodies of unknown affinity for their targets (reviewed in Bouchard and Schneider 2004; Benhenda et al. 2009; Wei et al. 2010b). Because the affinity of available HBx antibodies has not been determined, analysis of HBx protein levels can only be used to provide an estimate of HBx expression; moreover, comparison to expression level of other $\mathrm{HBV}$ proteins is inaccurate in the absence of affinity calculations for the antibodies used to detect these proteins. It, therefore, remains unknown whether HBx "overexpression" should be considered to have affected reported HBx activities, and recent studies that have compared $\mathrm{HBx}$ expressed alone (overexpressed) or in the context of HBV replication reported identical $\mathrm{HBx}$ effects in either context (Clippinger and Bouchard 2008; Clippinger et al. 2009; Gearhart and Bouchard 2010a; Yang and Bouchard 2012; Kim et al. 2013).

Finally, predictive models of $\mathrm{HBx}$ structure suggest that its amino-terminal region is unstructured, and it is possible that this may contribute to the ability of HBx to interact with a large number of cellular proteins and affect numerous cellular signal-transduction pathways (Hernandez et al. 2012). Interestingly, a number of recent reports that have addressed the multifunctional nature of viral regulatory proteins have shown that some multifunctional viral proteins can undergo structural rearrangements, particularly in regions of the protein characterized as unstructured, to interact with various cellular proteins and affect different aspects of the viral life cycle (Bornholdt et al. 2013; Ferreon et al. 2013). Moreover, some viral proteins can assemble and function as protein polymers that have multiple functions in their virus life cycle (Ou et al. 2012). Consequently, it is possible that the multiple functions ascribed to $\mathrm{HBx}$ may derive from structural rearrangements of $\mathrm{HBx}$, possibly in its unstructured amino-terminal region, which could occur throughout the HBV life cycle. 


\section{CONCLUDING REMARKS}

HBx can interact with multiple cellular proteins to either directly or indirectly regulate cellular and HBV gene expression, and can modulate numerous cellular signal-transduction pathways. Most of what we know about regulation of HBV transcription by HBx and of HBx modulation of cellular-signaling factors has been learned from transfected cells in culture, a milieu that differs dramatically from the in vivo setting. HBV is highly adapted for replication in well-differentiated hepatocytes with abundant liver-enriched transcription factors, and studies in established liver cell lines are unlikely to completely mimic the cellular environment encountered by HBV during infection of hepatocytes. Consequently, a precise understanding of the role of $\mathrm{HBx}$ during $\mathrm{HBV}$ replication and the myriad of HBx effects on hepatocyte physiology awaits the development of experimentally tractable in vivo model systems for analyzing $\mathrm{HBx}$ activities during a natural HBV infection. Interestingly, many of the $\mathrm{HBx}$ activities important for stimulating $\mathrm{HBV}$ replication may inadvertently contribute to the development of HBV-associated HCC. Defining the mechanisms that regulate $\mathrm{HBV}$ replication is essential for identifying novel therapeutic targets for treating individuals with a chronic HBV infection and at high risk for developing HCC.

\section{ACKNOWLEDGMENTS}

The authors thank Siddartha Rawat, Jason Lamontagne, and Marissa M. K. Minor for their preparation of the figures.

\section{REFERENCES}

Andrisani OM. 2013. Deregulation of epigenetic mechanisms by the hepatitis B virus X protein in hepatocarcinogenesis. Viruses 5: 858-872.

Andrisani OM, Barnabas S. 1999. The transcriptional function of the hepatitis B virus $\mathrm{X}$ protein and its role in hepatocarcinogenesis. Int J Oncol 15: 373-379.

Aufiero B, Schneider RJ. 1990. The hepatitis B virus X-gene product trans-activates both RNA polymerase II and III promoters. EMBO J 9: 497-504.

Balsano C, Billet O, Bennoun M, Cavard C, Zider A, Grimber G, Natoli G, Briand P, Levrero M. 1994. Hepatitis B virus $\mathrm{X}$ gene product acts as a transactivator in vivo. $J$ Hepatol 21: 103-109.

Barry M, Früh K. 2006. Viral modulators of Cullin RING ubiquitin ligases: Culling the host defense. Sci STKE 335: $1-5$.

Becker SA, Lee TH, Butel JS, Slagle BL. 1998. Hepatitis B virus X protein interferes with cellular DNA repair. J Virol 72: $266-272$.

Belloni L, Pollicino T, De Nicola F, Guerrieri F, Raffa G, Fanciulli M, Raimondo G, Levrero M. 2009. Nuclear $\mathrm{HBx}$ binds the HBV minichromosome and modifies the epigenetic regulation of cccDNA function. Proc Natl Acad Sci 106: 19975-19979.

Benhenda S, Cougot D, Buendia MA, Neuveut C. 2009. Hepatitis B virus X protein molecular functions and its role in virus life cycle and pathogenesis. Adv Cancer Res 103: 75-109.

Benhenda S, Ducroux A, Riviere L, Sobhian B, Ward MD, Dion S, Hantz O, Protzer U, Michel ML, Benkirane M, et al. 2013. Methyltransferase PRMT1 is a binding partner of $\mathrm{HBx}$ and a negative regulator of hepatitis B virus transcription. J Virol 87: 4360-4371.

Benn J, Schneider RJ. 1994. Hepatitis B virus HBx protein activates Ras-GTP complex formation and establishes a Ras, Raf, MAP kinase signaling cascade. Proc Natl Acad Sci 91: 10350-10354.

Benn J, Su F, Doria M, Schneider RJ. 1996. Hepatitis B virus $\mathrm{HBx}$ protein induces transcription factor AP-1 by activation of extracellular signal-regulated and c-Jun N-terminal mitogen-activated protein kinases. J Virol 70: 49784985.

Bergametti F, Prigent S, Luber B, Benoit A, Tiollais P, Sarasin A, Transy C. 1999. The proapoptotic effect of hepatitis B virus $\mathrm{HBx}$ protein correlates with its transactivation activity in stably transfected cell lines. Oncogene 18: 28602871.

Bergametti F, Sitterlin D, Transy C. 2002. Turnover of hepatitis $B$ virus $X$ protein is regulated by damaged DNAbinding complex. J Virol 76: 6495-6501.

Billet O, Grimber G, Levrero M, Seye KA, Briand P, Joulin V. 1995. In vivo activity of the hepatitis B virus core promoter: Tissue specificity and temporal regulation. J Virol 69: 5912-5916.

Bissig KD, Wieland SF, Tran P, Isogawa M, Le TT, Chisari TV, Verma IM. 2010. Human liver chimeric mice provide a model for hepatitis $\mathrm{B}$ and $\mathrm{C}$ virus infection and treatment. J Clin Invest 120: 924-930.

Blum HE, Zhang ZS, Galun E, von Weizsacher F, Garner B, Liang TJ, Wands JR. 1992. Hepatitis B virus X protein is not central to the viral life cycle in vitro. J Virol 66: 12231227.

Bock CT, Schranz P, Schroder CH, Zentgraf H. 1994. Hepatitis $\mathrm{B}$ virus genome is organized into nucleosomes in the nucleus of the infected cell. Virus Genes 8: 215-229.

Bock CT, Schwinn S, Locarnini S, Fyfe J, Manns MP, Trautwein C, Zentgraf H. 2001. Structural organization of the hepatitis B virus minichromosome. J Mol Biol 307: 183196.

Bornholdt ZA, Noda T, Abelson DM, Halfmann P, Wood MR, Kawaoka Y, Saphire EO. 2013. Structural rearrange- 
B.L. Slagle and M.J. Bouchard

ment of Ebola virus VP40 begets multiple functions in the virus life cycle. Cell 154: 763-774.

Bouchard MJ, Schneider RJ. 2004. The enigmatic X gene of hepatitis B virus. J Virol 78: 12725-12734.

Bouchard MJ, Wang LH, Schneider RJ. 2002. Calcium signaling by HBx protein in hepatitis B virus DNA replication. Science 294: 2376-2378.

Bouchard MJ, Puro RJ, Wang L, Schneider RJ. 2003. Activation and inhibition of cellular calcium and tyrosine kinase signaling pathways identify targets of the HBx protein involved in hepatitis B virus replication. J Virol 77: 7713-7719.

Casciano JC, Bagga S, Yang B, Bouchard MJ. 2012. Modulation of cell proliferation pathways by the hepatitis $\mathrm{B}$ virus X protein: A potential contributor to the development of hepatocellular carcinoma. In Hepatocellular carcinoma-Basic research (ed. Lau JWY), pp. 103-152. InTech, Rijeka, Croatia.

Chami M, Ferrari D, Nicotera P, Paterlini-Brechot P, Rizzuto R. 2003. Caspase-dependent alterations of $\mathrm{Ca}^{2+}$ signaling in the induction of apoptosis by hepatitis B virus X protein. J Biol Chem 278: 31745-31755.

Chen HS, Kaneko S, Girones R, Anderson RW, Hornbuckle WE, Tennant BC, Cote PJ, Gerin JL, Purcell RH, Miller RH. 1993. The woodchuck hepatitis virus $\mathrm{X}$ gene is important for establishment of virus infection in woodchucks. J Virol 67: 1218-1226.

Cheong JH, Yi MK, Lin Y, Murakami S. 1995. Human RPB5, a subunit shared by eukaryotic nuclear RNA polymerases, binds human hepatitis $\mathrm{B}$ virus $\mathrm{X}$ protein and may play a role in X transactivation. EMBO J 14: 143-150.

Choi BH, Park GT, Rho HM. 1999. Interaction of hepatitis B viral X protein and CCAAT/enhancer-binding protein $\alpha$ synergistically activates the hepatitis B viral enhancer II/ pregenomic promoter. J Biol Chem 274: 2858-2865.

Chou YC, Jeng KS, Chen ML, Liu HH, Liu TL, Chen YL, Liu YC, Hu CP, Chang C. 2005. Evaluation of transcriptional efficiency of hepatitis B virus covalently closed circular DNA by reverse transcription-PCR combined with the restriction enzyme digestion method. J Virol 79: 18131823.

Clippinger AJ, Bouchard MJ. 2008. The hepatitis B virus HBx protein localizes to mitochondria in primary rat hepatocytes and modulates mitochondrial membrane potential. J Virol 82: 6798-6811.

Clippinger AJ, Gearhart TL, Bouchard MJ. 2009. Hepatitis B virus $\mathrm{X}$ protein modulates apoptosis in primary rat hepatocytes by regulating both NF- $\mathrm{KB}$ and the mitochondrial permeability transition pore. J Virol 83: 4718-4731.

Colgrove R, Simon G, Ganem D. 1989. Transcriptional activation of homologous and heterologous genes by the hepatitis B virus X gene product in cells permissive for viral replication. J Virol 63: 4019-4026.

Cougot D, Wu Y, Cairo S, Caramel J, Renard CA, Levy L, Buendia MA, Neuveut C. 2007. The hepatitis B virus X protein functionally interacts with CREB-binding protein/p300 in the regulation of CREB-mediated transcription. J Biol Chem 282: 4277-4287.

Cougot D, Allemand E, Riviere L, Benhenda S, Duroure K, Levillayer F, Muchardt C, Buendia MA, Neuveut C. 2012. Inhibition of PP1 phosphatase activity by HBx: A mech- anism for the activation of hepatitis B virus transcription. Sci Signal 5: pra1.

Dandri M, Schirmacher P, Rogler CE. 1996. Woodchuck hepatitis virus $\mathrm{X}$ protein is present in chronically infected woodchuck liver and woodchuck hepatocellular carcinomas which are permissive for viral replication. J Virol 70: 5246-5254.

Dandri M, Burda MR, Torok E, Pollok JM, Iwanska A, Sommer G, Rogiers X, Rogler CE, Gupta S, Will H, et al. 2001. Repopulation of mouse liver with human hepatocytes and in vivo infection with hepatitis B virus. Hepatol 33: 981-988.

Dehart JL, Planelles V. 2008. Human immunodeficiency virus type 1 vpr links proteasomal degradation and checkpoint activation. J Virol 82: 1066-1072.

de Moura PR, Rui E, de Almeida GK, Kobarg J. 2005. The cysteine residues of the hepatitis B virus onco-protein HBx are not required for its interaction with RNA or with human p53. Virus Res 108: 121-131.

Diao J, Khine AA, Sarangi F, Hsu E, Iorio C, Tibbles LA, Woodgett JR, Penninger J, Richardson CD. 2001. X protein of hepatitis B virus inhibits Fas-mediated apoptosis and is associated with up-regulation of the SAPK/JNK pathway. J Biol Chem 276: 8328-8340.

Dirsch O, Rodicker F, Herborn CU, Hilken G, Putzer BM. 2004. Diagnosis of biliary duct cysts in transgenic mice expressing the hepatitis B virus X-protein. J Hepatol 40: 356-357.

Doria M, Klein N, Lucito R, Schneider RJ. 1995. The hepatitis $B$ virus $H B x$ protein is a dual specificity cytoplasmic activator of Ras and nuclear activator of transcription factors. $E M B O J$ 19: 4747-4757.

Du J, Zhou Y, Fu QX, Gong WL, Zhao F, Peng JC, Zhan LS. 2008. Bioluminescence imaging of hepatitis B virus enhancer and promoter activities in mice. FEBS Lett 582: 3552-3556.

Elmore LW, Hancock AR, Chang SF, Wang XW, Chang S, Callahan CP, Geller DA, Will H, Harris CC. 1997. Hepatitis $B$ virus $X$ protein and $\mathrm{p} 53$ tumor suppressor interactions in the modulation of apoptosis. Proc Natl Acad Sci 94: 14707-14712.

Ferreon AC, Ferreon JC, Wright PE, Deniz AA. 2013. Modulation of allostery by protein intrinsic disorder. Nature 498: 390-394.

Ganem D, Schneider RJ. 2001. Hepadnaviridae: The viruses and their replication. In Virology (ed. Knipe DM, Howley PM), pp. 2923-2969. Lippincott Williams \& Wilkins, Philadelphia.

Gearhart TL, Bouchard MJ. 2010a. Replication of the hepatitis $B$ virus requires a calcium-dependent $\mathrm{HBx}$-induced $\mathrm{G}_{1}$ phase arrest of hepatocytes. Virol 407: 14-25.

Gearhart TL, Bouchard MJ. 2010b. The hepatitis B virus X protein modulates hepatocyte proliferation pathways to stimulate viral replication. J Virol 84: 2675-2686.

Gearhart TL, Bouchard MJ. 2011. The hepatitis B virus HBx protein modulates cell cycle regulatory proteins in cultured primary human hepatocytes. Virus Res 155: 363367.

Glitsch MD, Bakowski D, Parekh AB. 2002. Store-operated $\mathrm{Ca}^{2+}$ entry depends on mitochondrial $\mathrm{Ca}^{2+}$ uptake. EMBO J 21: 6744-6754. 
Haviv I, Vaizel D, Shaul Y. 1996. pX, the HBV-encoded coactivator, interacts with components of the transcription machinery and stimulates transcription in a TAF-independent manner. EMBO J 15: 3413-3420.

Haviv I, Shamay M, Doitsh G, Shaul Y. 1998. Hepatitis B virus $\mathrm{pX}$ targets TFIIB in transcription coactivation. Mol Cell Biol 18: 1562-1569.

Hernandez S, Venegas M, Brahm J, Villanueva RD. 2012. The viral transactivator HBx protein exhibits a high potential for regulation via phosphorylation through an evolutionarily conserved mechanism. Infect Agent Cancer 7: 27.

Hodgson AJ, Keasler VV, Slagle BL. 2008. Premature cell cycle entry induced by hepatitis $\mathrm{B}$ virus regulatory $\mathrm{HBx}$ protein during compensatory liver regeneration. Cancer Res 68: 10341-10348.

Hodgson AJ, Hyser JM, Keasler VV, Cang Y, Slagle BL. 2012. Hepatitis $\mathrm{B}$ virus regulatory $\mathrm{HBx}$ protein binding to DDB1 is required but is not sufficient for maximal HBV replication. Virol 426: 73-82.

Jung JK, Arora P, Pagano JS, Jang KL. 2007. Expression of DNA methyltransferase 1 is activated by hepatitis B virus $\mathrm{X}$ protein via a regulatory circuit involving the p16INK4a-cyclin D1-CDK 4/6-pRb-E2F1 pathway. Cancer Res 67: 5771-5778.

Keasler VV, Slagle BL. 2008. The interaction of HBx with cellular DDB1. In The pleiotropic functions of the viral protein $H B x$ in hepatitis $B$ virus infection and the development of liver cancer (ed. Kobarg J), pp. 91-103. Research Signpost, Kerala, India.

Keasler VV, Lerat H, Madden CR, Finegold MJ, McGarvey MJ, Mohammed EMA, Forbes SJ, Lemon SM, Hadsell DL, Grona SJ, et al. 2006. Increased liver pathology in hepatitis $\mathrm{C}$ virus transgenic mice expressing the hepatitis B virus X protein. Virology 347: 466-475.

Keasler VV, Hodgson AJ, Madden CR, Slagle BL. 2007. Enhancement of hepatitis B virus replication by the regulatory X protein in vitro and in vivo. J Virol 81: 2656-2662.

Khattar E, Mukherji A, Kumar V. 2012. Akt augments the oncogenic potential of the HBx protein of hepatitis B virus by phosphorylation. FEBS J 279: 1220-1230.

Kim KH, Seong BL. 2003. Pro-apoptotic function of HBV X protein is mediated by interaction with c-FLIP and enhancement of death-inducing signal. EMBO J 22: $2104-$ 2116.

Kim CM, Koike K, Saito I, Miyamura T, Jay G. 1991. HBx gene of hepatitis $\mathrm{B}$ virus induces liver cancer in transgenic mice. Nature 351: 317-320.

Kim H, Lee H, Yun Y. 1998. X-gene product of hepatitis B virus induces apoptosis in liver cells. J Biol Chem 273: 381-385.

Kim KH, Shin HJ, Kim K, Choi HM, Rhee SH, Moon HB, Kim HH, Yang US, Yu DY, Cheong J. 2007a. Hepatitis B virus $\mathrm{X}$ protein induces hepatic steatosis via transcriptional activation of SREBP1 and PPAR $\gamma$. Gastroenterology 132: 1955-1967.

Kim S, Kim HY, Lee S, Kim SW, Sohn S, Kim K, Cho H. 2007b. Hepatitis B virus X protein induces perinuclear mitochondrial clustering in microtubule- and dyneindependent manners. J Virol 81: 1714-1726.
Kim SJ, Khan M, Quan J, Till A, Subramani S, Siddiqui A. 2013. Hepatitis B virus disrupts mitochondrial dynamics: Induces fission and mitophagy to attenuate apoptosis. PLoS Pathog 9: e1003722.

Klein NP, Schneider RJ. 1997. Activation of Src family kinases by hepatitis B virus HBx protein and coupled signaling to Ras. Mol Cell Biol 17: 6427-6436.

Klein NP, Bouchard MJ, Wang LH, Kobarg C, Schneider RJ. 1999. Src kinases involved in hepatitis B virus replication. EMBO J 18: 5019-5027.

Klein A, Guhl E, Tzeng TJ, Fuhrhop J, Levrero M, Graessmann M, Graessmann A. 2003. HBX causes cyclin D1 overexpression and development of breast cancer in transgenic animals that are heterozygous for p53. Oncogene 22: 2910-2919.

Kumar V, Sarkar DP. 2004. Hepatitis B virus X protein: Structure-function relationships and role in viral pathogenesis. In Transcription factors (ed. Gossen M, et al.), pp. 377-407. Springer, Heidelberg.

Kwee L, Lucito R, Aufiero B, Schneider RJ. 1992. Alternate translation initiation on hepatitis $\mathrm{B}$ virus $\mathrm{X}$ mRNA produces multiple polypeptides that differentially transactivate class II and III promoters. J Virol 66: 4382-4389.

Lara-Pezzi E, Armesilla AL, Majano PL, Redondo JM, Lopez-Cabrera M. 1998. The hepatitis B virus X protein activates nuclear factor of activated T cells (NF-AT) by a cyclosporin A-sensitive pathway. EMBO J 17: 70667077.

Lee J, Zhou P. 2007. DCAFs, the missing link of the Cul4DDB1 ubiquitin ligase. Mol Cell 26: 775-780.

Lee TH, Finegold MF, Shen RF, DeMayo JL, Woo SLC, Butel JS. 1990. Hepatitis B virus transactivator X protein is not tumorigenic in transgenic mice. J Virol 64: 5939-5947.

Lee TH, Elledge SJ, Butel JS. 1995. Hepatitis B virus X protein interacts with a probable cellular DNA repair protein. J Virol 69: 1107-1114.

Lee YI, Lee S, Lee Y, Bong YS, Hyun SW, Do Yoo Y, Kim SJ, Kim YW, Poo HR. 1998. The human hepatitis B virus transactivator $\mathrm{X}$ gene product regulates $\mathrm{Sp} 1$ mediated transcription of an insulin-like growth factor II promoter 4. Oncogene 16: 2367-2380.

Lee DK, Park SH, Yi Y, Choi SG, Lee C, Parks WT, Cho H, de Caestecker MP, Shaul Y, Roberts AB, et al. 2001a. The hepatitis $\mathrm{B}$ virus encoded oncoprotein $\mathrm{pX}$ amplifies TGF- $\beta$ family signaling through direct interaction with Smad4: Potential mechanism of hepatitis B virus-induced liver fibrosis. Genes Dev 15: 455-466.

Lee YI, Kang-Park S, Do SI, Lee YI. 2001b. The hepatitis B virus-X protein activates a phosphatidylinositol 3-kinase-dependent survival signaling cascade. J Biol Chem 276: 16969-16977.

Lee S, Tarn C, Wang WH, Chen S, Hullinger RL, Andrisani OM. 2002. Hepatitis B virus X protein differentially regulates cell cycle progression in X-transforming versus nontransforming hepatocyte (AML12) cell lines. J Biol Chem 277: 8730-8740.

Lee JO, Kwun HJ, Jung JK, Choi KH, Min DS, Jang KL. 2005. Hepatitis B virus X protein represses E-cadherin expression via activation of DNA methyltransferase 1. Oncogene 24: 6617-6625. 
B.L. Slagle and M.J. Bouchard

Lee SH, Cha EJ, Lim JE, Kwon SH, Kim DH, Cho H, Han KH. 2012. Structural characterization of an intrinsically unfolded mini-HBX protein from hepatitis B virus. Mol Cells 34: 165-169.

Leon DA, Herberg FW, Banky P, Taylor SS. 1997. A stable $\alpha$ helical domain at the $\mathrm{N}$ terminus of the RI $\alpha$ subunits of cAMP-dependent protein kinase is a novel dimerization/ docking motif. J Biol Chem 272: 28431-28437.

Leupin O, Bontron S, Schaeffer C, Strubin M. 2005. Hepatitis $B$ virus $X$ protein stimulates viral genome replication via a DDB1-dependent pathway distinct from that leading to cell death. J Virol 79: 4238-4245.

Li T, Robert EI, van Breugel PC, Strubin M, Zheng N. 2010. A promiscuous $\alpha$-helical motif anchors viral hijackers and substrate receptors to the CUL4-DDB1 ubiquitin ligase machinery. Nat Struct Mol Biol 17: 105-111.

Liang XZ, Pickering MT, Cho NH, Chang H, Volkert MR, Kowalik TF, Jung JU. 2006. Deregulation of DNA damage signal transduction by herpesvirus latency-associated M2. J Virol 80: 5862-5874.

Lin MH, Lo SC. 1989. Dimerization of hepatitis B viral X protein synthesized in a cell-free system. Biochem Biophys Res Commun 164: 14-21.

Lin Y, Nomura T, Cheong J, Dorjsuren D, Iida K, Murakami S. 1997a. Hepatitis B virus X protein is a transcriptional modulator that communicates with transcription factor IIB and the RNA polymerase II subunit 5. J Biol Chem 272: 7132-7139.

Lin Y, Nomura T, Yamashita T, Dorjsuren D, Tang H, Murakami S. 1997b. The transactivation and p53-interacting functions of hepatitis B virus X protein are mutually interfering but distinct. Cancer Res 57: 5137-5142.

Lin GY, Paterson RG, Richardson CD, Lamb RA. 1998. The $\mathrm{V}$ protein of paramyxovirus SV5 interacts with damagespecific DNA binding protein. Virology 249: 189-200.

Lizzano RA, Yang B, Clippinger AJ, Bouchard MJ. 2011. The C-terminal region of the hepatitis $\mathrm{B}$ virus $\mathrm{X}$ protein is essential for its stability and function. Virus Res 155: 231-239.

Locker JK, Griffiths G. 1999. An unconventional role for cytoplasmic disulfide bonds in vaccinia virus proteins. $J$ Cell Biol 144: 267-279.

Lucifora J, Protzer U. 2012. Hepatitis B virus X protein: A key regulator of the virus life cycle. In Viral GenomesMolecular structure, diversity, gene expression mechanisms and host-virus interactions (ed. Garcia ML, Romanowski V), pp. 141-154. InTech, Rijeka, Croatia.

Lucifora J, Arzberger S, Durantel D, Belloni L, Strubin M, Levrero M, Zoulim F, Hantz O, Protzer U. 2011. Hepatitis $B$ virus $X$ protein is essential to initiate and maintain virus replication after infection. J Hepatol 55: 996-1003.

Lucito RSR. 1993. Transcriptional activation by the hepatitis $\mathrm{B}$ virus X protein. In Regulation of gene expression in animal viruses (ed. Carrasco LEA), pp. 67-79. Plenum, New York.

Lucito R, Schneider RJ. 1992. Hepatitis B virus X protein activates transcription factor NF- $\mathrm{\kappa B}$ without a requirement for protein kinase C. J Virol 66: 983-991.

Madden CR, Slagle BL. 2001. Stimulation of cellular proliferation by hepatitis B virus X protein. Dis Markers 17: 153-157.
McCall CM, Hu J, Xiong Y. 2005. Recruiting substrates to cullin 4-dependent ubiquitin ligases by DDB1. Cell Cycle 4: 27-29.

Melegari M, Scaglioni PP, Wands JR. 1998. Cloning and characterization of a novel hepatitis B virus $\mathrm{X}$ binding protein that inhibits viral replication. J Virol 72: 1737-1743.

Melegari M, Wolf SK, Schneider RJ. 2005. Hepatitis B virus DNA replication is coordinated by core protein serine phosphorylation and HBx expression. J Virol 79: 98109820.

Mittal S, El-Serag HB. 2013. Epidemiology of hepatocellular carcinoma: Consider the population. J Clin Gastroenterol 47: S2-S6.

Moraleda G, Saputelli J, Aldrich CE, Averett D, Condreay L, Mason WS. 1997. Lack of effect of antiviral therapy in nondividing hepatocyte cultures on the closed circular DNA of woodchuck hepatitis virus. JVirol 71: 9392-9399.

Murakami S, Cheong J, Kaneko S. 1994. Human hepatitis virus $\mathrm{X}$ gene encodes a regulatory domain that represses transactivation of X protein. J Biol Chem 269: 15118 15123.

Nelson-Rees WA, Flandermeyer RR. 1976. HeLa cultures defined. Science 191: 96-98.

Neuveut C, Wei Y, Buendia MA. 2010. Mechanisms of HBVrelated hepatocarcinogenesis. J Hepatol 52: 594-604.

Newbold JE, Xin H, Tencza M, Sherman G, Dean J, Bowden S, Locarnini S. 1995. The covalently closed duplex form of the hepadnavirus genome exists in situ as a heterogeneous population of viral minichromosomes. J Virol 69: $3350-3357$.

O'Connell BC, Harper JW. 2007. Ubiquitin proteasome system (UPS): What can chromatin do for you? Curr Opin Cell Biol 19: 206-214.

Ou HD, Kwiatkowski W, Deerinck TJ, Noske A, Blain KY, Land HS, Soria C, Powers CJ, May AP, Shu X, et al. 2012. A structural basis for the assembly and functions of a viral polymer that inactivates multiple tumor suppressors. Cell 151: 304-319.

Pan J, Duan LX, Sun BS, Feitelson MA. 2001. Hepatitis B virus $\mathrm{X}$ protein protects against anti-Fas-mediated apoptosis in human liver cells by inducing NF-KB. $J$ Gen Virol 82: 171-182.

Park IY, Sohn BH, Yu E, Suh DJ, Chung YH, Lee JH, Surzycki SJ, Lee YI. 2007. Aberrant epigenetic modifications in hepatocarcinogenesis induced by hepatitis $\mathrm{B}$ virus $\mathrm{X}$ protein. Gastroenterology 132: 1476-1494.

Perini G, Oetjen E, Green MR. 1999. The hepatitis B pX protein promotes dimerization and DNA binding of cellular basic region/leucine zipper proteins by targeting the conserved basic region. J Biol Chem 274: 13970-13977.

Pollicino T, Belloni L, Raffa G, Pediconi N, Squadrito G, Raimondo G, Levrero M. 2006. Hepatitis B virus replication is regulated by the acetylation status of hepatitis $\mathrm{B}$ virus cccDNA-bound $\mathrm{H} 3$ and $\mathrm{H} 4$ histones. Gastroenterology 130: 823-837.

Precious B, Childs K, Fitzpatrick-Swallow V, Goodbourn S, Randall RE. 2005. Simian virus $5 \mathrm{~V}$ protein acts as an adaptor, linking DDB1 to STAT2, to facilitate the ubiquitination of STAT1. J Virol 79: 13434-13441.

Qadri I, Maguire HF, Siddiqui A. 1995. Hepatitis B virus transactivator protein $\mathrm{X}$ interacts with the TATA-binding protein. Proc Natl Acad Sci 92: 1003-1007. 
Qiu X, Zhang L, Lu S, Song Y, Lao Y, Hu J, Fan H. 2014. Upregulation of DNMT1 mediated by HBx suppresses RASSF1A expression independent of DNA methylation. Oncol Rep 31: 202-208.

Rahmani Z, Huh KW, Lasher R, Siddiqui A. 2000. Hepatitis $\mathrm{B}$ virus $\mathrm{X}$ protein colocalizes to mitochondria with a human voltage-dependent anion channel and alters its transmembrane potential. J Virol 74: 2840-2846.

Rawat S, Clippinger AJ, Bouchard MJ. 2012. Modulation of apoptotic signaling by the hepatitis B virus $\mathrm{X}$ protein. Viruses 4: 2945-2972.

Reifenberg K, Lohler J, Pudollek HP, Schmitteckert E, Spindler G, Kock J, Schlickt HJ. 1999a. Long-term expression of the hepatitis B virus core-e- and X-proteins does not cause pathologic changes in transgenic mice. J Hepatol 26: $119-130$.

Reifenberg K, Wilts H, Löhler J, Nusser P, Hanano R, Guidotti LG, Chisari FV, Schlicht HJ. 1999b. The hepatitis B virus $\mathrm{X}$ protein transactivates viral core gene expression in vivo. J Virol 73: 10399-10405.

Reifenberg K, Nusser P, Lohler J, Spindler G, Kuhn C, von Weizsacker F, Kock J. 2002. Virus replication and virion export in X-deficient hepatitis B virus transgenic mice. J Gen Virol 83: 991-996.

Riviere L, Ducroux A, Buendia MA. 2014. The oncogenic role of hepatitis B virus. Recent Results Cancer Res 193: 59-74.

Scaglioni PP, Melegari M, Wands JR. 1997. Posttranscriptional regulation of hepatitis $\mathrm{B}$ virus replication by the precore protein. J Virol 71: 345-353.

Schek N, Bartenschlager R, Kuhn C, Schaller H. 1991. Phosphorylation and rapid turnover of hepatitis $\mathrm{B}$ virus $\mathrm{X}$ protein expressed in HepG2 cells from a recombinant vaccinia virus. Oncogene 6: $1735-1744$.

Schrem H, Klempnauer J, Borlak J. 2002. Liver-enriched transcription factors in liver function and development: Part I. The hepatocyte nuclear factor network and liverspecific gene expression. Pharmacol Rev 54: 129-158.

Schrem H, Klempnauer J, Borlak J. 2004. Liver-enriched transcription factors in liver function and development: Part II. The C/EBPs and D site-binding protein in cell cycle control, carcinogenesis, circadian gene regulation, liver regeneration, apoptosis, and liver-specific gene regulation. Pharmaco Rev 56: 291-330.

Schrofelbauer B, Hakata Y, Landau NR. 2007. HIV-1 Vpr function is mediated by interaction with the damagespecific DNA-binding protein DDB1. Proc Natl Acad Sci 104: 4130-4135.

Seeger C, Zoulim F, Mason WS. 2007. Hepadnaviruses. In Fields virology (ed. Knipe DM, et al.), pp. 2977-3029. Lippincott Williams \& Wilkins, Philadelphia.

Seeger C, Zoulim F, Mason WS. 2013. Hepadnaviruses. In Fields virology (ed. Knipe DM, Howley PM), pp. 2185 2221. Lippincott Williams \& Wilkins, Philadelphia.

Shih WL, Kuo ML, Chuang SE, Cheng AL, Doong SL. 2000. Hepatitis $B$ virus $X$ protein inhibits transforming growth factor-B-induced apoptosis through the activation of phosphatidylinositol 3-kinase pathway. J Biol Chem 275: $25858-25864$.
Shirakata Y, Koike K. 2003. Hepatitis B virus X protein induces cell death by causing loss of mitochondrial membrane potential. J Biol Chem 278: 22071-22078.

Sirma H, Weil R, Rosmorduc O, Urban S, Israël A, Kremsdorf D, Bréchot C. 1998. Cytosol is the prime compartment of hepatitis B virus X protein where it colocalizes with the proteasome. Oncogene 16: 2051-2063.

Sitterlin D, Lee TH, Prigent S, Tiollais P, Butel JS, Transy C. 1997. Interaction of the UV-damaged DNA-binding protein with hepatitis B virus X protein is conserved among mammalian hepadnaviruses and restricted to transactivation-proficient X-insertion mutants. J Virol 71: 61946199.

Slagle BL, Lee TH, Medina D, Finegold MJ, Butel JS. 1996. Increased sensitivity to the hepatocarcinogen diethylnitrosamine in transgenic mice carrying the hepatitis B virus X gene. Molec Carcinog 15: 261-269.

Sohn JA, Litwin S, Seeger C. 2009. Mechanism for CCC DNA synthesis in hepadnaviruses. PLoS ONE 4: e8093.

Su F, Schneider RJ. 1996. Hepatitis B virus HBx protein activates transcription factor NF- $\mathrm{\kappa B}$ by acting on multiple cytoplasmic inhibitors or $\mathrm{rel}$-related proteins. J Virol 70: $4558-4566$.

Takada S, Shirakata Y, Kaneniwa N, Koike K. 1999. Association of hepatitis B virus $\mathrm{X}$ protein with mitochondria causes mitochondrial aggregation at the nuclear periphery, leading to cell death. Oncogene 18: 6965-6973.

Tang H, Delgermaa L, Huang FJ, Oishi N, Liu L, He F, Zhao LS, Murakami S. 2005. The transcriptional transactivation function of $\mathrm{HBx}$ protein is important for its augmentation role in hepatitis B virus replication. J Virol 79: 5548-5556.

Tarn C, Lee S, Hu Y, Ashendel C, Andrisani OM. 2001. Hepatitis B virus $X$ protein differentially activates RASRAF-MAPK and JNK pathways in X-transforming versus non-transforming AML12 hepatocytes. J Biol Chem 276: 34671-34680.

Tarn C, Zou L, Hullinger RL, Andrisani OM. 2002. Hepatitis $B$ virus $X$ protein activates the $\mathrm{p} 38$ mitogen-activated protein kinase pathway in dedifferentiated hepatocytes. I Virol 76: 9763-9772.

Tian Y, Sir D, Kuo CF, Ann DK, Ou JH. 2011. Autophagy required for hepatitis B virus replication in transgenic mice. J Virol 85: 13453-13456.

Tiollais P, Charnay P, Vyas GN. 1981. Biology of hepatitis B virus. Science 213: 406-411.

Tralhao JG, Roudier J, Morosan S, Giannini C, Tu H, Goulenok C, Carnot F, Zavala F, Joulin V, Kremsdorf D, et al. 2002. Paracrine in vivo inhibitory effects of hepatitis $B$ virus $\mathrm{X}$ protein $(\mathrm{HBx})$ on liver cell proliferation: An alternative mechanism of $\mathrm{HBx}$-related pathogenesis. Proc Natl Acad Sci 99: 6991-6996.

Tsuge M, Hiraga N, Akiyama R, Tanaka S, Matsushita M, Mitsui F, Abe H, Kitamura S, Hatakeyama T, Kimura T, et al. 2010. HBx protein is indispensable for development of viraemia in human hepatocyte chimeric mice. J Gen Virol 91: $1854-1864$.

Tuttleman JS, Pourcel C, Summers J. 1986. Formation of the pool of covalently closed circular viral DNA in hepadnavirus-infected cells. Cell 47: 451-460. 
Urban S, Hildt E, Eckerskorn C, Sirma H, Kekule A, Hofschneider PH. 1997. Isolation and molecular characterization of hepatitis B virus X-protein from a baculovirus expression system. Hepatology 26: 1045-1053.

van Breugel PC, Robert EI, Mueller H, Decorsiere A, Zoulim F, Hantz O, Strubin M. 2012. Hepatitis B virus X protein stimulates gene expression selectively from extrachromosomal DNA templates. Hepatology 56: 2116-2124.

van Hemert FJ, van de Klundert MA, Lukashov VV, Kootstra NA, Berkhout B, Zaaijer HL. 2011. Protein X of hepatitis $B$ virus: Origin and structure similarity with the central domain of DNA glycosylase. PLoS ONE 6: e23392.

Wang WH, Yuh CH, Dang CV, Johnson DL. 1995. The hepatitis $B$ virus $X$ protein increases the cellular level of TATAbinding protein, which mediates transactivation of RNA polymerase III genes. Mol Cell Biol 15: 6720-6728.

Wang WH, Trivedi A, Johnson DL. 1997. Hepatitis B virus X protein induces RNA polymerase III-dependent gene transcription and increases cellular TATA-binding protein by activating the Ras signaling pathway. Mol Cell Biol 17: 6838-6846.

Wang WH, Trivedi A, Johnson DL. 1998. Regulation of RNA polymerase I-dependent promoters by the hepatitis B virus $\mathrm{X}$ protein via activated Ras and TATA-binding protein. Mol Cell Biol 18: 7086-7094.

Wang WH, Gregori G, Hullinger RL, Andrisani OM. 2004 Sustained activation of p38 mitogen-activated protein kinase and c-Jun $\mathrm{N}$-terminal kinase pathways by hepatitis $\mathrm{B}$ virus $\mathrm{X}$ protein mediates apoptosis via induction of Fas/FasL and tumor necrosis factor (TNF) receptor 1/ TNF- $\alpha$ expression. Mol Cell Biol 24: 10352-10365.

Wang WH, Hullinger RL, Andrisani OM. 2008. Hepatitis B virus $\mathrm{X}$ protein via the $\mathrm{p} 38 \mathrm{MAPK}$ pathway induces $\mathrm{E} 2 \mathrm{~F} 1$ release and ATR kinase activation mediating p53 apoptosis. J Biol Chem 283: 25455-25467.

Wang WH, Studach LL, Andrisani OM. 2011. Proteins ZNF198 and SUZ12 are down-regulated in hepatitis B virus (HBV) X protein-mediated hepatocyte transformation and in HBV replication. Hepatology 53: 1137-1147.

Wang C, Yang W, Yan HX, Luo T, Zhang J, Tang L, Wu FQ, Zhang HL, Yu LX, Zheng LY, et al. 2012. Hepatitis B virus $\mathrm{X}(\mathrm{HBx})$ induces tumorigenicity of hepatic progenitor cells in 3,5-diethoxycarbonyl-1,4-dihydrocollidine-treated HBx transgenic mice. Hepatology 55: 108-120.

Waris G, Huh KW, Siddiqui A. 2001. Mitochondrially associated hepatitis $\mathrm{B}$ virus $\mathrm{X}$ protein consitutively activates transcription factors STAT-3 and NF-KB via oxidative stress. Mol Cell Biol 21: 7721-7730.

Wei C, Ni C, Song T, Liu Y, Yang X, Zheng Z, Jia Y, Yuan Y, Guan K, Xu Y, et al. 2010a. The hepatitis B virus X protein disrupts innate immunity by downregulating mitochondrial antiviral signaling protein. J Immunol 185: 1158 1168.

Wei Y, Neuveut C, Tiollais P, Buendia MA. 2010b. Molecular biology of the hepatitis $\mathrm{B}$ virus and role of the $\mathrm{X}$ gene. Pathol Biol (Paris) 58: 267-272.

Williams JS, Andrisani OM. 1995. The hepatitis B virus X protein targets the basic region-leucine zipper domain of CREB. Proc Natl Acad Sci 92: 3819-3823.

Wu CG, Forgues M, Siddique S, Farnsworth J, Valerie K, Wang XW. 2002. SAGE transcript profiles of normal pri- mary human hepatocytes expressing oncogenic hepatitis B virus X protein. FASEB J 16: 1665-1667.

Wu BK, Li CC, Chen HJ, Chang JL, Jeng KS, Chou CK, Hsu MT, Tsai TF. 2006. Blocking of $\mathrm{G}_{1} / \mathrm{S}$ transition and cell death in the regenerating liver of Hepatitis B virus X protein transgenic mice. Biochem Biophys Res Commun 340: $916-928$.

Xu Z, Yen TSB, Wu L, Madden CR, Tan W, Slagle BL, Ou JH. 2002. Enhancement of hepatitis B virus replication by its X protein in transgenic mice. J Virol 76: 2579-2584.

Yan H, Zhong G, Xu G, He W, Jing Z, Gao Z, Huang Y, Qi Y, Peng B, Wang H, et al. 2012. Sodium taurocholate cotransporting polypeptide is a functional receptor for human hepatitis B and D virus. eLife 1: e00049.

Yan H, Peng B, He W, Zhong G, Qi Y, Ren B, Gao Z, Jing Z, Song M, Xu G, et al. 2013. Molecular determinants of hepatitis $\mathrm{B}$ and $\mathrm{D}$ virus entry restriction in mouse sodium taurocholate cotransporting polypeptide. J Virol 87: 7977-7991.

Yang B, Bouchard MJ. 2012. The hepatitis B virus X protein elevates cytosolic calcium signals by modulating mitochondrial calcium uptake. J Virol 86: 313-327.

Yen TSB. 1996. Hepadnaviral X protein: Review of recent progress. J Biomed Sci 3: 20-30.

Yoo YG, Oh SH, Park ES, Cho H, Lee N, Park H, Kim DK, Yu DY, Seong JK, Lee MO. 2003. Hepatitis B virus X protein enhances transcriptional activity of hypoxia-inducible factor- $1 \alpha$ through activation of mitogen-activated protein kinase pathway. J Biol Chem 278: 39076-39084.

Yu DY, Moon HB, Son JK, Jeong S, Yu SL, Yoon H, Han YM, Lee CS, Park JS, Lee CH, et al. 1999. Incidence of hepatocellular carcinoma in transgenic mice expressing the hepatitis B virus X-protein. J Hepatol 31: 123-132.

Zhang ZS, Torii N, Furusaka A, Malayaman N, Hu ZY, Liang TJ. 2000. Structural and functional characterization of interaction between hepatitis $\mathrm{B}$ virus $\mathrm{X}$ protein and the proteasome complex. J Biol Chem 275: 15157-15165.

Zhang ZS, Torii N, Hu Z, Jacob J, Liang TJ. 2001. X-deficient woodchuck hepatitis virus mutants behave like attenuated viruses and induce protective immunity in vivo. J Clin Invest 108: 1523-1531.

Zhang WY, Xu FQ, Shan CL, Xiang R, Ye LH, Zhang XD. 2009. Gene expression profiles of human liver cells mediated by hepatitis B virus X protein. Acta Pharmacol Sin 30: $424-434$.

Zhong G, Yan H, Wang H, He W, Jing Z, Qi Y, Fu L, Gao Z, Huang Y, Xu G, et al. 2013. Sodium taurocholate cotransporting polypeptide mediates woolly monkey hepatitis $\mathrm{B}$ virus infection of Tupaia hepatocytes. J Virol 87: 71767184.

Zhu HZ, Wang Y, Chen JQ, Cheng GX, Xue JL. 2004. Transgenic mice expressing hepatitis $\mathrm{B}$ virus $\mathrm{X}$ protein are more susceptible to carcinogen induced hepatocarcinogenesis. Exp Molec Path 76: 44-50.

Zoulim F. 2005. New insight on hepatitis B virus persistence from the study of intrahepatic viral cccDNA.J Hepatol 42: 302-308.

Zoulim F, Saputelli J, Seeger C. 1994. Woodchuck hepatitis virus $\mathrm{X}$ protein is required for viral infection in vivo. $J$ Virol 68: 2026-2030. 


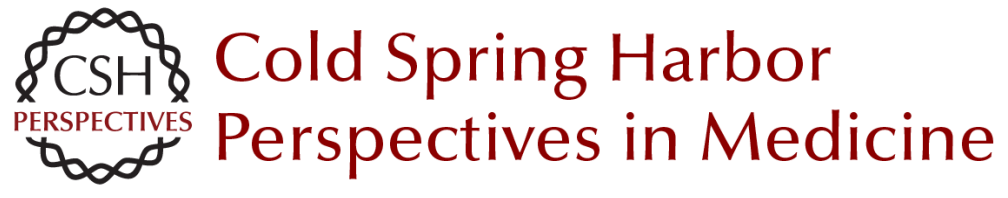

\section{Hepatitis B Virus X and Regulation of Viral Gene Expression}

Betty L. Slagle and Michael J. Bouchard

Cold Spring Harb Perspect Med 2016; doi: 10.1101/cshperspect.a021402 originally published online January 8, 2016

Subject Collection The Hepatitis B and Delta Viruses

Hepatitis B Virus X and Regulation of Viral Gene Expression

Betty L. Slagle and Michael J. Bouchard

The Woodchuck, a Nonprimate Model for Immunopathogenesis and Therapeutic Immunomodulation in Chronic Hepatitis B Virus Infection

Michael Roggendorf, Anna D. Kosinska, Jia Liu, et al.

Mouse Models of Hepatitis B Virus Pathogenesis Matteo lannacone and Luca G. Guidotti

Therapy of Delta Hepatitis Cihan Yurdaydin and Ramazan Idilman

Immune Response in Hepatitis B Virus Infection Anthony Tan, Sarene Koh and Antonio Bertoletti

Hepatitis D Virus: Introduction and Epidemiology Mario Rizzetto

Management of Chronic Hepatitis B in Patients from Special Populations

Ching-Lung Lai and Man-Fung Yuen

Hepatitis B Virus Genotypes and Variants Chih-Lin Lin and Jia-Horng Kao
Origins and Evolution of Hepatitis B Virus and Hepatitis D Virus

Margaret Littlejohn, Stephen Locarnini and Lilly Yuen

Assembly and Release of Hepatitis B Virus Lisa Selzer and Adam Zlotnick

Hepatitis D Virus Replication John M. Taylor

Treatment of Liver Cancer Chun-Yu Liu, Kuen-Feng Chen and Pei-Jer Chen

Hepatitis B Virus and Hepatitis D Virus Entry, Species Specificity, and Tissue Tropism Koichi Watashi and Takaji Wakita

Hepadnavirus Genome Replication and

Persistence Jianming Hu and Christoph Seeger

The Chimpanzee Model for Hepatitis B Virus Infection

Stefan F. Wieland

Hepatitis B Virus Epidemiology

Jennifer H. MacLachlan and Benjamin C. Cowie

For additional articles in this collection, see http://perspectivesinmedicine.cshlp.org/cgi/collection/ 